\title{
A method to estimate the longshore sediment transport at ebb-tidal deltas based on their volumetric growth: application to the Guadiana (Spain-Portugal border)
}

\author{
Erwan Garel ${ }^{1 *}$, Alejandro López-Ruiz ${ }^{2}$, Óscar Ferreira ${ }^{1}$ \\ ${ }^{1}$ Centre for Marine and Environmental Research (CIMA), University of Algarve, Faro, Portugal \\ ${ }^{2}$ Departamento de Ingeniería Aeroespacial y Mecánica de Fluidos, Universidad de Sevilla, Spain \\ *Corresponding author (egarel@ualg.pt)
}

\author{
Personal authors' version \\ Accepted article for publication in Earth Surface Processes and Landforms \\ https://doi.org/10.1002/esp.4679
}

\begin{abstract}
Current techniques assessing longshore sediment transport rates have large uncertainties, pleading for the development of alternative and complementary approaches. The present study proposes a method to estimate the decadal average rate of longshore transport at modern ebb-tidal deltas based on a sediment budget analysis of the outer shoal growth. This transport is obtained as the balance of the other contributions to the shoal with the total sediment input rate obtained from an inverse application of the inlet reservoir model. The method is applied to the Guadiana ebb-tidal delta, yielding an average longshore sediment transport rate $(-85,000 \mathrm{~m} 3 / \mathrm{yr})$ in good agreement with expectations for the region. It is exemplified that this decadal averaged rate can be used to improve longshore sediment transport expressions in order to study its variability over shorter time scales. At the Guadiana, the yearly longshore sediment transport from the improved formula ranges from $-25,000 \mathrm{~m} 3$ (westward) to $-245,000 \mathrm{~m} 3$ (eastward) and is related to the North Atlantic Oscillation index. Overall, the proposed method constitutes an alternative tool to constrain the average longshore sediment transport rate over decades in the vicinity of tidal inlets. It is applicable to ebb-tidal deltas where the outer shoal growth (from an early to a mature stage) is well-documented by bathymetric maps, and where the main transport pathways towards the outer shoal can be specified.
\end{abstract}

Keywords: Longshore transport; Ebb-tidal delta; Inlet Reservoir Model; CERC equation; NAO index. 


\section{Introduction}

Longshore sediment transport (LST) is the main driver of the shoreline planform evolution along many coastal environments and must be reliably quantified for sustainable management and planning (CERC, 1984, Dean and Dalrymple, 2004, Komar, 1998). The most common LST estimations are obtained from the application of empirical bulk equations like the ones proposed by Komar and Inman (1970), Bijker's (1971), CERC (1984), Kamphuis (1991), or Bayram et al. (2007) and derivations/improvements of those (e.g., López-Ruiz et al., 2014, Mil-Homens et al., 2013, Valle et al., 1993). These equations are based on waves and physical properties in the surf zone, since longshore transport results mainly from currents produced by oblique incident breaking waves (Longuet-Higgins, 1970), and are calibrated against - or rather adjusted to (see Cooper and Pilkey, 2004) - data measured in the field or in laboratory experiments. The resulting expressions are explicit and easily implemented with limited information from the site but are known to have large uncertainties (Bayram et al., 2001, Esteves et al., 2009, Güner et al., 2011, Schoonees and Theron, 1993, Wang et al., 1998). In particular, LST predictions can vary widely depending of the bulk formula which is used (Fowler et al., 1995, Güner et al., 2011, Mil-Homens et al., 2013, Schoonees and Theron, 2001, Tonk and Masselink, 2005, Van Wellen et al., 2000, Wang et al., 1998). Direct quantifications at the site are required to calibrate (or improve, at least) bulk equations or validate their results, but are rarely available (Cooper and Pilkey, 2004, Smith et al., 2009).

Tracing techniques (e.g., Ciavola et al., 1997, Inman et al., 1980, Tonk and Masselink, 2005), sediment traps (e.g., Dean et al., 1982, Kraus and Dean, 1987, Tonk and Masselink, 2005, Wang et al., 1998) and OBS measurements (e.g., Tonk and Masselink, 2005) are commonly used to quantify the LST over the short-term. Quantitative information at longer time scales (e.g., yearly, decadal) can be obtained from the analysis of shoreline or topo-bathymetric changes like at barrier spits (Aagaard et al., 2004, Lee and Birkemeier, 1993). Similarly, direct observations of the volume of the littoral drift accumulated against engineering structures (jetties, groins and breakwaters) can provide solid estimates of the longshore transport considering the entire beach system (rather than the upper beach, only) if the cross-shore transport is negligible or well-quantified (e.g., Bodge and Dean, 1987, Bruno et al., 1981, Dean et al., 1982, Güner et al., 2011, Schoonees et al., 2006, Wang and Kraus, 1999). Some authors have also assessed LST rates based on the infilling of frequently dredged pits at harbours (e.g., Patsch and Griggs, 2008). Besides, sediment budget analyses - establishing the balance of volumes for sources and sinks along a portion of the coast during a given time (Bowen and Inman, 1966, Rosati, 2005) - are also frequently implemented to constrain the LST within regional sediment cells (e.g., Kaminsky et al., 2010, Patsch and Griggs, 2008, Santos et al., 2014). However, all these techniques have uncertainties linked to the measurement methods, to 
the complexity of the transport process and to the large temporal (from hours to centuries) and spatial (from tens of meters to hundreds of kilometres) scales at which the longshore transport impacts nearshore environments (Cowell et al., 2003a, Cowell et al., 2003b, Hanson et al., 2003, Larson and Kraus, 1995). Assessing the longshore transport is especially difficult over long time periods when the scale range is wide. There is, therefore, a need to develop alternative or complementary assessment methods to constrain the medium to long term (years to decades) LST based on field evidences (Stive et al., 2002).

In the present study, an innovative approach is described to constrain the medium term (decadal) LST rate at the updrift beach of ebb-tidal deltas based on a sediment budget analysis of the outer shoal development. The method is applicable to deltas where the outer shoal growth from an early to a mature stage is well-documented by bathymetric maps, and requires the specification of the main sediment transport pathways across the inlet. Through the reverse application of an aggregate model, the decadal average LST rate is constrained as best estimate along with upper prediction bounds at confidence intervals (useful to define coastal management strategies). The results obtained at a case study are compared with predictions from various bulk equations and further used, as an example, to adjust the CERC (1984) formula in order to assess the yearly LST rate variability.

\section{Regional setting}

The study area encompasses the ebb-tidal delta (ebb delta, hereafter) of the Guadiana estuary, at the southern border between Spain and Portugal (Figure 1). Referring to the terminology of Hayes (1980), the Guadiana is a mixed-energy, tide-dominated inlet (Morales, 1997). The tidal regime in the area is semi-diurnal with a mean range of $2 \mathrm{~m}$. Waves of moderate energy dominate the offshore wave climate, with yearly average significant height and peak period of $1 \mathrm{~m}$ and $8.2 \mathrm{~s}$, respectively (Costa et al., 2001). The wave field (see Figure 1) comprises both swell and sea waves from the W-SW directions (71\% occurrence) and mostly sea waves from the SE (23\% of occurrences).

Before jetty installation in 1972-1974, the historical ebb delta was broad, asymmetric eastwards and characterized by the presence of a large sandy shoal (the O'Bril bank) in front of the estuary mouth (Gonzalez et al., 2001). In 1969, for instance, the bank was -1 $\mathrm{km}$ wide and extended $-4 \mathrm{~km}$ eastward from the western margin (see dashed black contour in Figure 1). In response to tidal flow stabilisation and constriction by jetties, the eastern part of the historical delta collapsed, while a modern ebb delta formed off the mouth (Garel et al., 2014). The modern delta developed into an inlet channel scoured into the O'Bril bank, bounded by sand storage areas. The latter areas include a relatively straight updrift lateral bar and an outer shoal - or ebb shoal "proper" following Kraus (2000) terminology with a typical horseshoe shape in plan view marked by a series of sub-parallel lobate swash bars. In the east, the outer shoal connects to a broad downdrift complex, which corresponds 
to the swash platform of the historical delta (Figure 1) and is affected by widespread erosion (Garel et al., 2014). Dredging of the outer shoal was performed in 1987 and 2015 to improve the navigability of the entrance channel (see Garel, 2017).

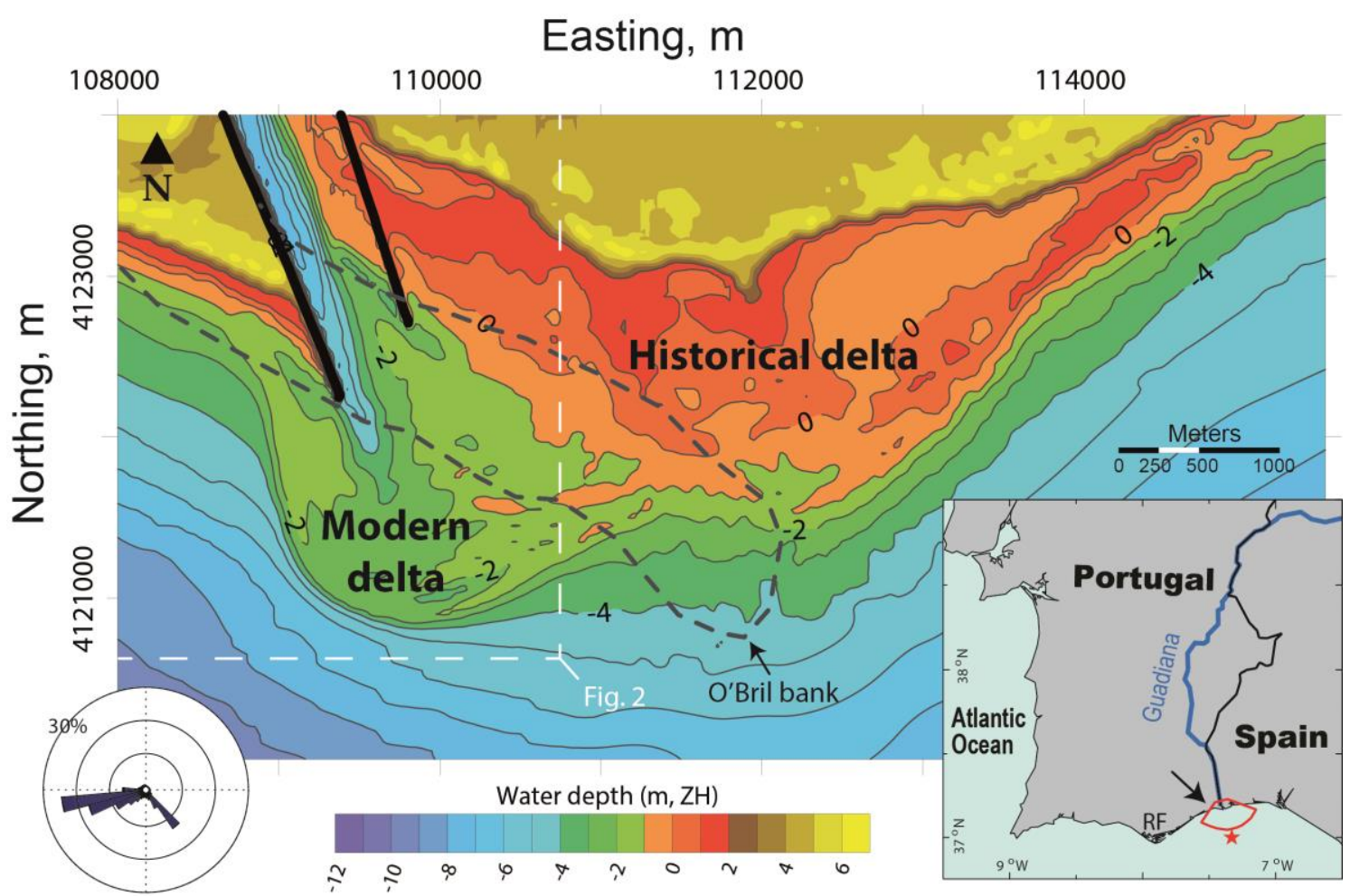

Figure 1. Composite topo-bathymetric map of the Guadiana estuary ebb-tidal delta (as in 2014) with indication of the O'Bril bank before jetty installation (as in 1969, dashed line). Water depths have a contour interval of $1 \mathrm{~m}$ and are referred to the hydrographic zero ( $\mathrm{ZH}, 2 \mathrm{~m}$ below mean sea level). The white dashed rectangle corresponds to the area represented in Figure 2. For general location, see the arrow in the inset, with indication of the Ria Formosa (RF), SWAN model computational grid (red area) and SIMAR point (red star). The wave field (based on the significant wave height at the SIMAR point 5026021) is shown on the lower left corner.

The grain size in the area shows a large variability (between fine and coarse sand), typical of deltaic environments (see the Iberian Atlantic Margin Sediments Database described in Costas et al., 2018). The updrift beach is constituted with fine sand of mean grain size $\left(\mathrm{D}_{50}\right)$ about $0.3 \mathrm{~mm}$ in average. Sand with a similar $\mathrm{D}_{50}$ is only observed on the downdrift swash platform, where part of the bypassed material is expected to deposit. The $\mathrm{D}_{50}$ at the lateral updrift bar is much coarser $(2 \mathrm{~mm})$, indicating a very energetic area exposed to SW storms constituted mainly with lagged material.

The LST direction in the region is always reported to be from west to east (Andrade, 1990, Bettencourt, 1994, CEEPYC, 1979, Cuena, 1991, Gonzalez et al., 2001, Granja et al., 1984, Santos et al., 2014, Vicente and Pereira, 2001). The proposed regional rate estimates vary widely, from a minimum of $6,000 \mathrm{~m}^{3} / \mathrm{yr}$ obtained by Andrade (1990) to a maximum of 300,000 $\mathrm{m}^{3} / \mathrm{yr}$ (Consulmar, 1989 in Bettencourt, 1994, Vicente and Pereira, 2001). Results for the east flank of Ria Formosa (immediately updrift of the study area; see Figure 
1) range between $100,000 \mathrm{~m}^{3} / \mathrm{yr}$ (Andrade, 1990) and 150,000 $\mathrm{m}^{3} /$ year (Bettencourt, 1994). At the study site, a local rate of $180,000 \mathrm{~m}^{3} / \mathrm{yr}$ was established based on sand accumulation against the western jetty (Gonzalez et al., 2001). This value is considered a high estimate as a large part of this accumulation results from cross-shore transport due to the welding of a sandbank to the beach following jetty installation (Garel et al., 2015). Based on rough qualitative assessments about sediment sources and losses in the sediment cell, Santos et al. (2014) consider that the LST rate must be less than the one of the adjacent sediment cell in the West, $110,000 \mathrm{~m}^{3} / \mathrm{yr}$.

\section{Methods}

\section{Description of the approach}

The proposed approach uses the Inlet Reservoir Model (IRM), an analytical aggregate model based on mass conservation that describes the long-term volumetric evolution of ebb deltas and evaluates the associated bypassing rate (Kraus, 2000, Kraus, 2002). The model requires the partitioning of the delta in distinct morphological elements that correspond to different deposition areas (so-called "reservoirs") embracing the main transport pathways across the inlet. Such elements typically include the external bars of the ebb delta (Carr and Kraus, 2001, FitzGerald et al., 2000), and possibly other features depending of the complexity of the system (e.g., Cox and Howe, 2012, Dabees and Kraus, 2004, Dabees and Kraus, 2005, Dabees and Kraus, 2008). The volumetric growth of the outer shoal, only, is considered for the present model application. This is typically the first element of the modern delta to develop after barrier breaching or jetty installation.

The IRM assumes that the outer shoal (like the other reservoirs) has an equilibrium volume $\left(\mathrm{V}_{\mathrm{e}}\right)$ corresponding to a maximum sand-retention capacity that is limited by wave action and cannot be exceeded. Its volume $\mathrm{V}(\mathrm{t})$ increases through time as sediment is brought to it. Meanwhile, the shoal is continuously "leaking" (i.e., bypassing) an increasing fraction of sand downdrift. Borderline cases are at the initial development of the shoal (most sediment arriving at the shoal deposits on it) and at the final development stage when its volume is close to equilibrium (most sediment arriving is bypassed). The model further assumes that the sand input rate to the outer shoal $\left(\mathrm{Q}_{\text {in }}\right)$ is proportionally linear to the sand output rate downdrift (Q $\left.Q_{\text {out }}\right)$. In this case, the volumetric evolution of the outer shoal is described as:

$$
V(t)=V_{e} \times\left(1-e^{\left(-\frac{Q_{i n}}{V_{e}} \times t\right)}\right)
$$

It is noted that through the application of the same procedure to the other reservoirs, the model implicitly accounts for the temporal storage of material, for example within migrating sand waves and swash bars. For further details about the model, the reader is referred to Kraus (2002). 
The sediment input rate $\mathrm{Q}_{\text {in }}$ in $\mathrm{Eq}(1)$ represents all the sediment that feeds the outer shoal from various sources. It generally corresponds to the longshore transport plus other significant contributions related to back-barrier or river export and to the erosion of local features such as the historical delta. For typical IRM implementation, $Q_{\text {in }}$ is estimated from numerical models or coastal-processes information from other studies (e.g., Cox and Howe, 2012, Dabees and Kraus, 2004, Dabees and Kraus, 2005, Dabees and Kraus, 2008, Kraus, 2000). By contrast, in the proposed approach $Q_{\text {in }}$ is not known beforehand but derived (along with $\mathrm{V}_{\mathrm{e}}$ ) from the best fit between predictions with $\mathrm{Eq}(1)$ and observations of the outer shoal volume. This is an inverse application of the model that relies on the availability of a relatively large bathymetric dataset describing the modern delta development.

To estimate the longshore transport, a sediment budget analysis is conducted at the outer shoal. The analysis requires the establishment of the main sources of sand that feed the outer shoal and of the associated sediment transport pathways. The input rates (other than longshore transport) are estimated from previous or complementary studies (see the Guadiana case study example) and averaged over the study period. The balance of these contributions with $\mathrm{Q}_{\text {in }}$ (obtained from the reverse IRM application) allows constraining the longshore sediment transport rate, noted $\mathrm{LST}_{\mathrm{BA}}$ hereafter. This rate represents the decadal averaged yearly volume of sediment that reached the delta from the updrift beach through longshore transport. It is important to note that by using the largest possible number of bathymetries and by considering averaged rates over the study period, the approach aims at smoothing out any shorter term LST variability.

\section{Implementation at the Guadiana ebb delta}

The volumetric evolution of the Guadiana ebb delta was evaluated based on a series of 13 bathymetric maps ranging from 1969 to 2017 (Table 1). The time interval in between the maps is irregular being at maximum 10 years (1995-2005) and at minimum 1 year (from 2014 to 2017). The original material (raw data, grids or maps) were converted into ED50 UTM29N projection system and standardized to a $25 \mathrm{~m}$ grid size. Water depths in this study are referred to the hydrographic zero which is $2 \mathrm{~m}$ below mean sea level. The bathymetry of 1969 represents the surface before jetties' completion and is used as reference to measure the volume of the morphological elements that constitute the modern ebb delta (Dean and Walton, 1975). It is noted that this is 3 years before the beginning of the jetty construction (1972, which is also the initial time of the IRM simulations). Yet, in between 1969 and 1972, the area was mainly constituted by the O’Bril bank (see Figure 1, black dashed contour), which was a rather stable feature at a yearly time scale (see Gonzalez et al., 2001). Therefore, it is reasonable to consider that the bathymetry did not change significantly during these 3 years and that the reference grid of 1969 represents adequately the pre-jetty surface. 
Table 1. List and attributes of the bathymetric maps of the Guadiana ebb-tidal delta used in the present study. MPW: Ministry of Public Works, Hydrography Section; IPTM: Port and Maritime Transport Institute; IH: Hydrographic Institute; UAlg: University of Algarve; SB: Single-Beam echo-sounder. $\Delta z(m)$ indicates the difference with the previous bathymetry at deep areas.

\begin{tabular}{|l|l|l|l|}
\hline Year & Source & Data & $\Delta z=z(t)-z(t-1)$ \\
\hline 1969 & MPW & Digitalised topo-bathymetric map 1/5000 & - \\
\hline 1977 & IPTM & Digitalised topo-bathymetric map 1/5000 & +0.05 \\
\hline 1982 & IPTM & Digitalised topo-bathymetric map 1/5000 & +0.25 \\
\hline 1986 & MPW & Digitalised topo-bathymetric map 1/5000 & -0.10 \\
\hline 1988 & MPW & Digitalised topo-bathymetric map 1/5000 & +0.20 \\
\hline 1992 & IPTM & Digitalised topo-bathymetric map 1/5000 & 0 \\
\hline 1995 & IH & 50 m grid size & +0.5 \\
\hline 2005 & IH & 25 m grid size & 0 \\
\hline 2010 & IH & 25 m grid size & 0 \\
\hline 2014 & UAlg & SB, 50 m transect interval & 0 \\
\hline 2015 & UAlg & SB, 50 m transect interval & 0 \\
\hline 2016 & UAlg & SB, 50 m transect interval & 0 \\
\hline 2017 & UAlg & SB, 50 m transect interval & 0 \\
\hline
\end{tabular}

Three morphological elements were distinguished for the establishment of their volumetric evolution: the updrift lateral bar, the inlet channel and the outer shoal (Figure 2). Typical at jettied inlets (Bruun and Gerritsen, 1959, Carr and Kraus, 2001, FitzGerald et al., 2000, Gaudiano and Kana, 2001), these features correspond to the main transport pathways from the updrift beach of the delta towards the downdrift complex (Figure 2). The updrift lateral bar receives mainly sediment from the longshore transport ( $\mathrm{LST}_{\mathrm{BA}}$ in Figure 2). From there, sediment is transported towards the outer shoal $\left(\mathrm{Q}_{\text {во }}\right)$ and within the inlet channel $\left(\mathrm{Q}_{\mathrm{BI}}\right)$ by wave and current actions. The inlet channel also receives sand exports from the Guadiana River estuary (RE). The material from both the updrift lateral bar and inlet channel feeds the outer shoal ( $\mathrm{Q}_{\mathrm{BO}}$ and $\mathrm{Q}_{\mathrm{IO}}$, respectively) from where sand is transported towards the downdrift complex $\left(\mathrm{Q}_{\mathrm{out}}\right)$, considered as the final sediment sink (since the focus is on the outer shoal evolution, only). In the Results Section, the input rates from the local sources to the outer shoal ( $\mathrm{Q}_{\text {Iо }}$ and $\mathrm{Q}_{\mathrm{BO}}$ ) are derived from observed volume variations of the inlet channel and lateral bar. Likewise, the average river export (RE) is established based on the refinement of previous estimates from a numerical model, updated with the results from more recent observational surveys. Qout is not reported as it is not required to estimate $\mathrm{LST}_{\mathrm{BA}}$. 

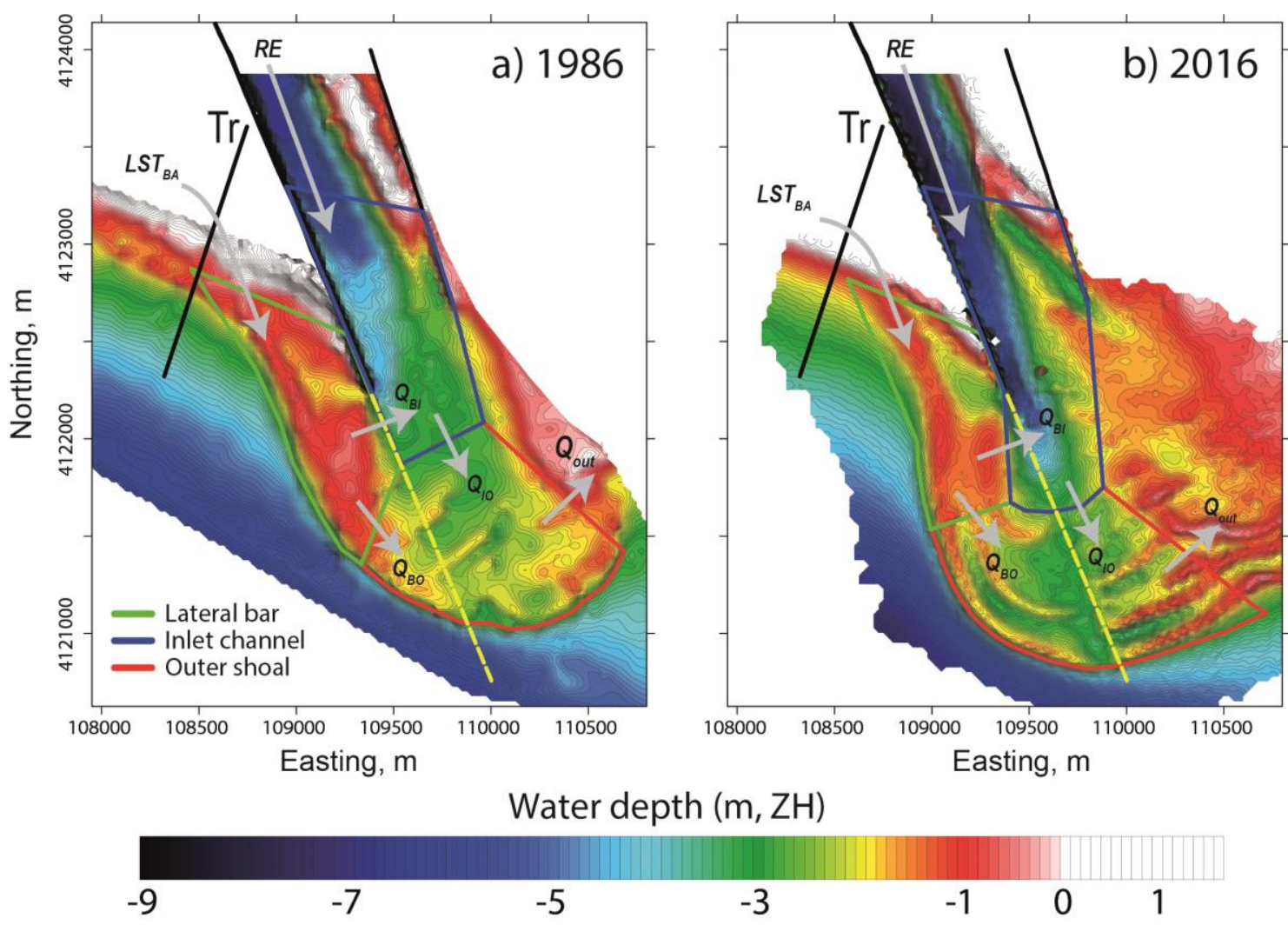

Figure 2. Map of the Guadiana ebb-tidal delta in 1986 (a) and 2016 (b) showing the location of the outer shoal, updrift lateral bar and inlet channel areas (red, green and blue boundaries, respectively). The contour interval is $0.10 \mathrm{~m}$. The grey arrows indicate the main transport pathways over the delta (see text for the definitions of $L S T_{B A}$ $R E, Q_{B}, Q_{I O}, Q_{B O}$ and $\left.Q_{o u t}\right)$. The offshore distance of the outer shoal is established along the yellow dashed line extending from the tip of the western jetty. The location of the cross-shore profile used to compute the LST with the bulk expressions is indicated with a black line (Tr). For general localisation of the study area, see Figure 1.

The above described sediment transport pathways are considered as the main ones across ebb-tidal inlets. Former morphodynamic analyses of the historical delta collapse (after jetty installation) based on aerial photographs revealed some updrift transport from the downdrift complex towards the inlet channel, with the westward extension of sand banks that started to overtop the eastern jetty in the early 2000s' (Garel et al., 2014). This transport cannot be quantified in this study due to map coverage limitations but is probably relatively weak due to sheltering from wave actions by the jetties and by the extended shoals of the historical delta (see Figure 1). Inputs from the downdrift complex back into the channel are therefore considered minor in comparison with the main contributors: the eastward LST $\mathrm{BA}_{\mathrm{BA}}$ and river exports RE (Figure 2). Likewise, the rather constant morphology and isobaths seaward of the outer shoal suggests that sand transport to deeper water is negligible.

The three above-defined elements were already clearly identified in 1977 (i.e., the first map available after jetty installation; see supplementary material). Their boundaries have variable position through time, identified based on the morpho-structural patterns of the maps with $0.1 \mathrm{~m}$ contour lines (see Figure 2). The external limits of both the updrift lateral bar and 
outer shoal were considered as the $-3 \mathrm{~m}$ isobaths, which delineate well the seaward border of the delta on each map. The outer shoal corresponds to the area that includes the subparallel lobate swash bars off the mouth. It is bounded landward by the inlet channel, which rises sharply seaward in the vicinity of the outer shoal. The precise limit between both areas is marked by the gentler channel thalweg slope that generally corresponds to the foot of the most landward (lobate) bars of the outer shoal. The outer shoal is limited laterally by the updrift (in the West) and downdrift (in the East) areas. These boundaries correspond to the transition from the lobate bars of the outer shoal to the broader, shallower and straighter bars of lateral areas. The eastern limit (between the outer shoal and downdrift areas) is also marked from the 2000s' by a sharp change in the bars orientation (e.g., Figure 2b). The landward limit of the updrift lateral bar is parallel to the beach, and correspond to the $-1 \mathrm{~m}$ isobaths along the beach face that is not affected by the presence of the delta (e.g., in the West of $\operatorname{Tr}$ in Figure 2); this is the location closest to the beach which is common to all the maps. Due to cross-shore transport, the beach accreted substantially during the initial growth of the modern delta, along with jetty impoundment, and has been relatively stable since then (see Figure 5a in Garel et al., 2015); all the littoral drift from the updrift beach is therefore considered to reach the ebb delta. In the east, the updrift lateral bar is limited by the inlet channel area. The border between these areas is the line drawn between the jetty tip and northwest corner of the outer shoal area (see Figure 2). In this way, all the bars observed on the updrift side of the inlet channel are included in the updrift area. The inlet channel area extends seaward until the outer shoal, and is limited laterally by the jetties, updrift lateral bar and downdrift complex (defined by the line drawn between the eastern jetty tip and the outer shoal). The northern limit of the inlet channel area is common for all maps, except that of 2017, which has a limited extension landward in between the jetties (see supplementary material) and for which the inlet channel volume was thus not computed. This limit was set to include in the area the portion of the O'Bril bank located in 1969 in between the future jetties (see black dashed line in Figure 1), and that was scoured by jet currents. Finally, following Stauble (1998), the offshore migration of the ebb delta is measured along the line extending seaward from the western jetty until the external boundary of the outer shoal (Figure 2, yellow dashed line). All the bathymetric maps with indication of the selected areas are reported as supplementary material.

The exact boundaries of the above defined morphological elements are intricate and diffuse, inducing some uncertainties in the (volume and area) estimates (Rosati, 2005). Various tests have shown however than slight modifications of the boundaries' positions does not significantly affect the results. Furthermore, uncertainties associated with volume estimates depend on the data acquisition (accuracy, extent of coverage and density of the points) and post-processing (Kraus and Rosati, 1999), for which information was generally not available. For example, significant vertical shifts (up to $0.5 \mathrm{~m}$ ) were observed for some consecutive maps before 2005, based on water depth comparisons at the deepest and 
furthest areas from the delta, supposed to be the most stable (Table 1); it is not known if these shifts are due to vertical errors or (at least partly) to genuine changes in bed elevation. Overall, these potential vertical errors should should be smoothed and have minor effects on the results since the morphological analysis focus on the long-term average ( 45 years) evolution of the ebb delta.

\section{LST from bulk equations}

For comparison with the results from the sediment budget analysis ( $\mathrm{LST}_{\mathrm{BA}}$ ), the longshore transport rate was computed through a cross-shore beach profile located in the west of the updrift lateral bar (see $\mathrm{Tr}$ in Figure 2), using various bulk equations: (1) the commonly used Kamphuis (1991) formula; (2) the well-known CERC (1984) using the recommended value of $\mathrm{K}=0.39$, where $\mathrm{K}$ is a sediment transport coefficient that accounts for all the parameters that are ignored by the equation, such as sediment and beach properties; (3) the CERC (1984) equation where the coefficient $\mathrm{K}$ was related to the $\mathrm{D}_{50}$ based on the relation derived empirically by del Valle et al. (1993), considering the average $\mathrm{D}_{50}(0.35 \mathrm{~mm})$ near $\operatorname{Tr}$ (obtained from the Iberian Atlantic Margin Sediments Database; see Costas et al., 2018); and, (4) the enhanced CERC formula proposed by Mil-Homens et al. (2013) through optimization algorithms applied to an extensive dataset. Hourly LST rates were obtained for the period 1972-2017 using the equations mentioned at the above points 1 to 4 and referred to as $\mathrm{LST}_{\mathrm{Kamp}}$, $\mathrm{LST}_{\mathrm{CERC} 1}, \mathrm{LST}_{\mathrm{CERC} 2}$ and $\mathrm{LST}_{\mathrm{CERC} 3}$, respectively.

To obtain the above LST values, a downscaling technique satisfactory applied at other coastal areas was implemented (for details, see Bergillos et al., 2016, López-Ruiz et al., 2018a, López-Ruiz et al., 2018b). A database of 500 representative deep water wave conditions was defined using the hindcast data from SIMAR point 5026021 (see Figure 1). These sea states were propagated to the nearshore to obtain the wave breaking conditions using the SWAN model (Booij et al., 1999) over a computational domain (see red area in Figure 1 inset) defined by a single curvilinear grid with variable resolution ranging between $-60 \times 60 \mathrm{~m}$ at the open ocean to $15 \times 15 \mathrm{~m}$ at the coastal area. All the cases of the database were propagated over the 2016 bathymetry, only, due to limited data availability in deep water depths and in the vicinity of $\mathrm{Tr}$; the implications of such simplification are discussed in section "Comparison with predictions from bulk equations". To compute the LST, the complete dataset of breaking wave conditions between 1972 and 2017 was reconstructed by means of interpolation based on radial basis functions. The yearly LST estimates obtained from hourly data range from the beginning of July of the preceding year to the end of June of the actual year, in order to match the acquisition of the bathymetric data (generally in summer, although not always known) and to integrate the entire maritime winter (from October to March) in the same yearly record. For example, the LST rate for year 2010 was estimated based on wave conditions from 1 July 2009 to 30 June 2010. 


\section{Results}

\section{Morphometric evolution of the ebb delta}

The morphometric evolution of the delta is detailed to correctly define the sediment pathways and volume exchanges between the outer shoal, inlet channel and lateral bar areas. The initial modern delta development was marked by fast $(-80 \mathrm{~m} / \mathrm{yr})$ offshore migration between 1977 and 1982 under ebb jets action, slowing down to $-7.5 \mathrm{~m} / \mathrm{yr}$ afterwards (Figure 3a). All the three elements also featured a rapid evolution during the first decade after jetty construction. In particular, $-2 \mathrm{Mm}^{3}$ of sand had been scoured in 1986 by ebb jets to form the inlet channel (Figure 3b, blue). The scoured material has contributed to the rapid growth of the outer shoal, which was more than $1.5 \mathrm{Mm}^{3}$ in 1982 (Figure $3 \mathrm{~b}$, red). The updrift lateral bar development was less significant and slower, with the accumulation of $\sim 1 \mathrm{Mm}^{3}$ from 1969 to 1988 (Figure 3b, green). From the 1990s' onward, each of the three elements displayed distinctive volume evolution trends: the outer shoal has been growing continuously, the updrift lateral bar has been slightly eroding, and the inlet channel has remained relatively stable (Figure $3 \mathrm{~b}$ ). For example, the volume compared to the mean for the period $1995-2017$ increased from $-25 \%$ to $+20 \%$ at the outer shoal, decreased from $+50 \%$ to $-30 \%$ at the updrift lateral bar and varied by less than $10 \%$ at the inlet channel area. Some points out of the trends, such as the volume decrease of the lateral bar in 2005, are attributed to short-lived natural shifts of the delta from its average evolution over longer time scales.

Similar to volume variations, the areas of the three elements show a rapid initial development until $\sim 1990$, before stabilising (Figure 3c). For example, variations were generally less than $10 \%$ of the mean for the period 1995-2017. This indicates that the volume evolutions of the outer shoal (growth) and updrift lateral bar (decrease) after the 1990s' were mainly achieved through vertical changes (accretion and erosion, respectively) rather than area variations, despite the ongoing delta offshore migration. Concordantly, the average vertical changes and volumetric evolution trends are similar for both elements (Figure 3b, d). The only significant divergence is observed during the initial development of the outer shoal (until 1988), when the average sand deposit decreased (Figure 3d, red) due to a redistribution of the sand from the O'Bril bank over an area expanding rapidly in deeper water (Figure 3c, red). In 2017, more than $3 \mathrm{~m}$ of sand, in average, was deposited on top of the pre-jetty surface at the outer shoal (Figure 3d). For the same period, the updrift area eroded by $\sim 0.7 \mathrm{~m}$, decreasing in volume from $\sim 1 \mathrm{Mm}^{3}$ (1988) to $\sim 0.5 \mathrm{Mm}^{3}$ (2017). This erosion corresponds to the reworking of a relatively broad and shallow shoal (relict of the O'Bril bank), resulting in a better defined (straighter and narrower) updrift lateral bar linking the beach to the outer shoal (compare 1982 and 1986 in supplementary material). Finally, it is also noted that the volumes of dredged material in 1987 and 2015 
were too low (e.g., $0.063 \mathrm{Mm}^{3}$ in 2015 , corresponding to a vertical average shift of $\sim 0.02$ $\mathrm{m}$ over the outer shoal) to have a notable impact on the volume evolution of the delta morphological elements (see Garel, 2017).
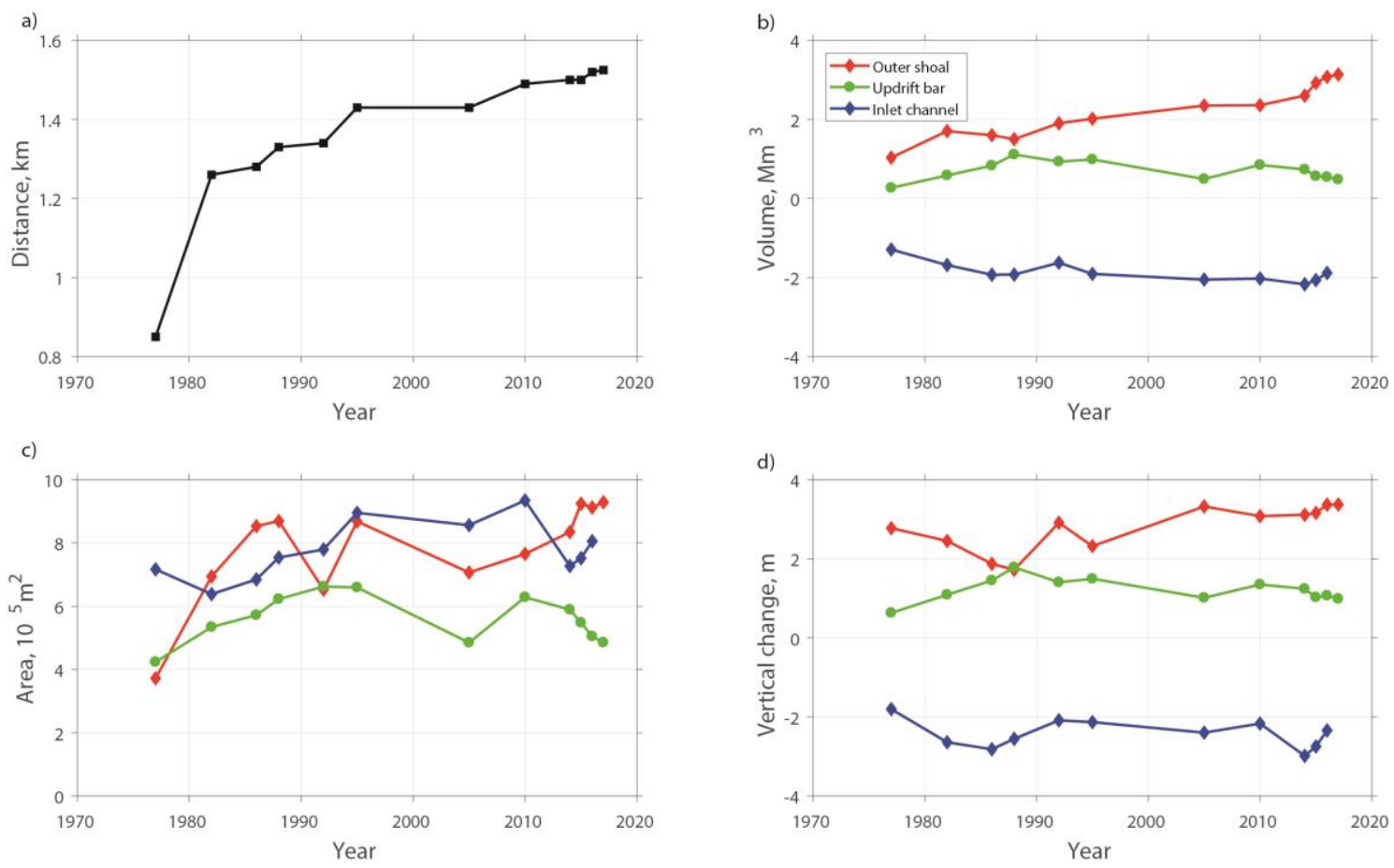

Figure 3. Evolution of the ebb-tidal delta as represented by its offshore distance from the jetty (a), the volume (b), the area (c) and the averaged vertical change (d) of the outer shoal (red lines), updrift lateral bar (green lines) and inlet channel (blue lines).

\section{Sediment budget analysis}

Transport pathways

The above morphometric results indicate that the inlet channel area did not store sediment after jetty installation (scouring of $-2 \mathrm{Mm}^{3}$ in 1972-86, stable volume afterward). Thus, the material that reached this element (see RE and $\mathrm{Q}_{\mathrm{BI}}$ in Figure 4) was transported directly to the outer shoal. Along with the sediment scoured locally ( $\mathrm{Q}_{s c}$ in Figure 4), these contributions represents the total sediment inputs from the inlet channel to the outer shoal (QIO in Figure 4). 


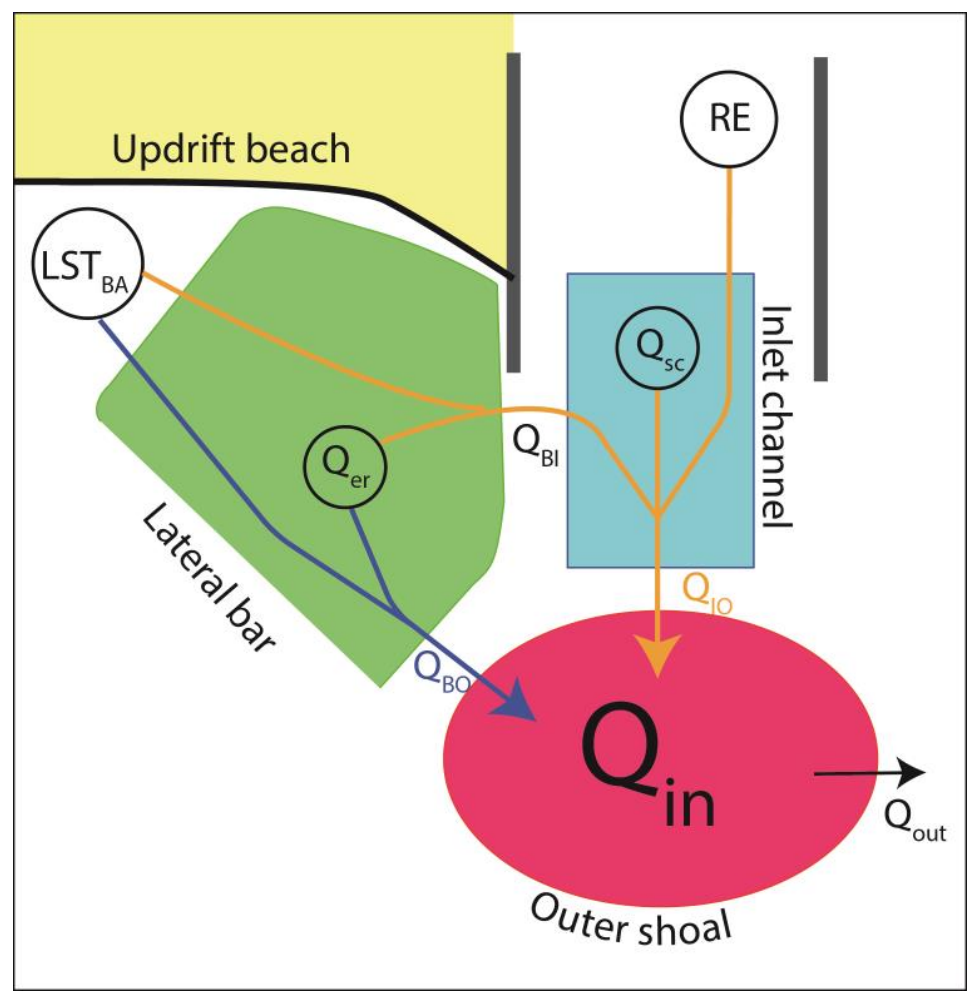

Figure 4. Schematic representation of the sediment inputs to the outer shoal $\left(Q_{i n}\right)$. The contributions that are ultimately delivered to the outer shoal from the updrift lateral bar area $\left(Q_{B O}\right)$ are indicated with blue arrows and from the inlet channel area $\left(Q_{I O}\right)$ with yellow arrows. $Q_{\text {er }}$ and $Q_{s c}$ represent local erosion and scouring at the updrift lateral bar and inlet channel, respectively. $L S T_{B A}$ is the longshore transport and RE is the river export. Qout is the export rate from the outer shoal to the downdrift complex, not evaluated in the present study. Overall, $Q_{i n}$ is the sum of the contributions indicated with circles. See also Figure 2.

Regarding the updrift lateral bar area, morphometric observations (Figure 3) indicate an initial period of growth (until 1988) followed by erosion. Downdrift and updrift lateral bars are usually fed with sand transported from the outer shoal by wave action, and thus develop after the outer shoal has reached a sufficient size (Kraus, 2002). In addition, at settings with a predominant LST direction updrift wave-induced transport is generally too weak to produce an updrift lateral bar (Kraus, 2002, Kraus, 2009). The observed early development of the updrift area at the study site is atypical and derives from the reworking of the O'Bril bank (providing a large local sand supply) rather than longshore transport (Garel et al., 2015). Since this growing phase is followed by erosion, it can be considered that all the littoral drift that arrived to this area (from the updrift beach) was transported to the inlet channel and outer shoal (see $\mathrm{LST}_{\mathrm{BA}}$ in Figure 4). The contribution of the updrift lateral bar to the outer shoal $\left(\mathrm{Q}_{\mathrm{BO}}\right.$ in Figure 4) consists of a fraction of the $\mathrm{LST}_{\mathrm{BA}}$ plus a fraction of the material eroded locally $\left(\mathrm{Q}_{\mathrm{er}}\right.$ in Figure 4). The other fractions are transported to the inlet channel and correspond to $\mathrm{Q}_{\mathrm{BI}}$ (Figure 4). Since the inlet channel acts as a conduit for sediment, the totality of $\mathrm{LST}_{\mathrm{BA}}$ and $\mathrm{Q}_{\mathrm{er}}$ ultimately feeds the outer shoal through $\mathrm{Q}_{\mathrm{IO}}$ and $\mathrm{Q}_{\mathrm{BO}}$ (Figure 4). Overall, the main sources of sand supplied to the outer shoal $\left(\mathrm{Q}_{\mathrm{in}}\right)$ are the $\mathrm{LST}_{\mathrm{BA}}, \mathrm{RE}, \mathrm{Q}_{\mathrm{er}}$ and $\mathrm{Q}_{\mathrm{sc}}$ :

$$
\mathrm{Q}_{\mathrm{in}}=\mathrm{LST}_{\mathrm{BA}}+\mathrm{RE}+\mathrm{Q}_{\mathrm{er}}+\mathrm{Q}_{\mathrm{sc}}
$$


In the following section, $\mathrm{LST}_{\mathrm{BA}}$ is constrained based on the evaluation of the other terms of $\mathrm{Eq}(2)$, i.e., $\mathrm{Q}_{\mathrm{in}}, \mathrm{RE}, \mathrm{Q}_{\mathrm{er}}$ and $\mathrm{Q}_{\text {sc. In particular, }}$ in is estimated based on a reverse application of the IRM, providing an average rate for the study period (1972-2017). Thus, the other assessed rates $\left(\mathrm{RE}, \mathrm{Q}_{\mathrm{er}}\right.$ and $\left.\mathrm{Q}_{\mathrm{sc}}\right)$ are also averaged for the same period, even though some temporal variability has been observed (for example, inlet channel scouring ( $\left.Q_{s c}\right)$ occurred during the $1^{\text {st }}$ decade after jetty installation).

\section{Sediment transport rates}

The average sediment input to the outer shoal ( $Q_{\text {in }}$ ) over the period 1972-2017 is estimated as the best fit between observations and volume predictions using $\mathrm{Eq}(1)$. The best fit $\left(\mathrm{r}^{2}=\right.$ 0.92 ) corresponds to an equilibrium volume $\left(\mathrm{V}_{\mathrm{e}}\right)$ of $3.16 \mathrm{Mm}^{3}$ with $75 \%$ prediction bounds of -2.8 and $3.5 \mathrm{Mm}^{3}$. The best estimate of $\mathrm{Q}_{\text {in }}$ is $-160,000 \mathrm{~m}^{3} / \mathrm{yr}$ with $75 \%$ prediction bounds of $\sim 103,000$ and $223,000 \mathrm{~m}^{3} / \mathrm{yr}$ (Figure 5).

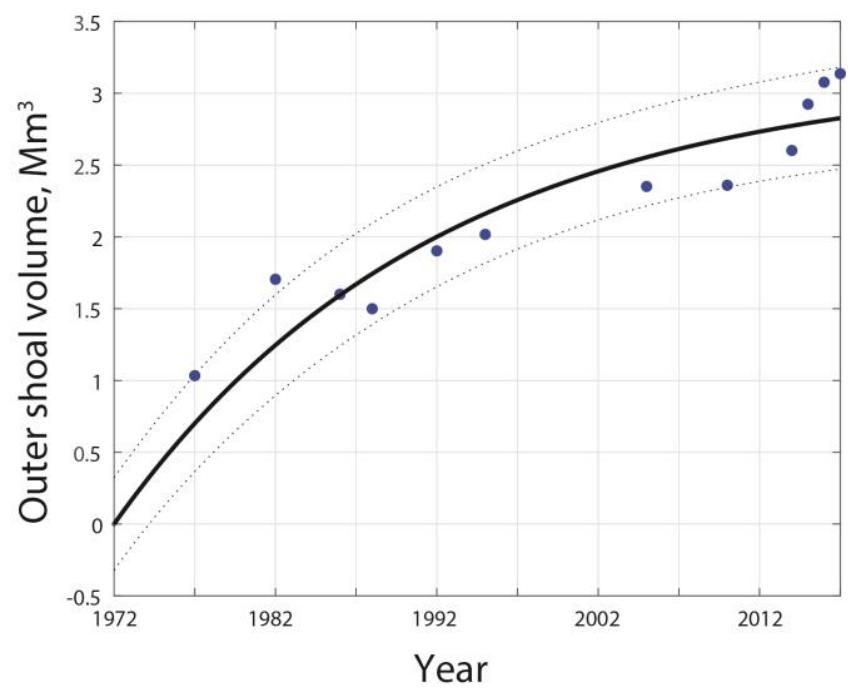

Figure 5. Volumetric evolution of the outer shoal from observations (dots) and predictions (best fit) from Eq(1) (black solid line) with upper and lower $75 \%$ prediction bounds in dashed.

According to the results depicted in Figure 3, a volume of $-2 \mathrm{Mm}^{3}$ was scoured by ebb jets during the first 10 years of the inlet channel development. Over the study period ( 45 years), this scouring represents an average sediment transport rate $Q_{s c}$ of $-44,000 \mathrm{~m}^{3} / \mathrm{yr}$. Furthermore, the volume of the updrift lateral bar has been reducing by $\sim 0.5 \mathrm{Mm}^{3}$ since the 90s', corresponding to an average transport rate $Q_{\text {er }}$ of $\sim 11,000 \mathrm{~m}^{3} / \mathrm{yr}$ from 1972 to 2017.

The volume of sand delivered from the estuary to the ebb delta (RE) is poorly constrained and depends largely of the river discharge and vertical stratification of estuarine waters. Observations suggests that sand export is significant for discharges $>1,500 \mathrm{~m}^{3} / \mathrm{s}$ (i.e., when the entire estuary is filled up with freshwater) but weak for lower rates. For example, during a discharge event of $1,000 \mathrm{~m}^{3} / \mathrm{s}$, a salt wedge developed at the mouth of the estuary, 
promoting near bed flows oriented upstream such that the sediment export was of the same order of magnitude than for low flow conditions (Garel and Ferreira, 2011). Based on an uncalibrated 2D model, an upper limit for RE of $100,000 \mathrm{~m}^{3} / \mathrm{yr}$ was proposed by weighting the simulated yearly sand transport for various river discharges to the frequency of occurrence of such events (Portela, 2006). This value seems large compared with other similar long and narrow systems. For example, at the Saco Estuary the yearly sand export is $10,000-16,000 \mathrm{~m}^{3}$, mainly during spring freshets that can last for weeks (Kelley et al., 2005). Part of the overestimation might be due to stratification effects, not reproduced with the $2 \mathrm{D}$ model. Furthermore, the predicted export rate for low discharge conditions $\left(30,000 \mathrm{~m}^{3} / \mathrm{yr}\right)$ is questionably high, being for example one order of magnitude larger than more recent estimates $\left(-5,000 \mathrm{~m}^{3} / \mathrm{yr}\right)$ based on cross-channel velocity measurements (Garel and Ferreira, 2011). Finally, since 2002 the river inflow is being strongly regulated by the large Alqueva dam (Garel and D'Alimonte, 2017), reducing the sand export by at least one order of magnitude (Garel and Ferreira, 2011). Following Portela's weighting method (see Table 1 in Portela 2006) but with the latter (low) rate for either any river discharge below $1,500 \mathrm{~m}^{3} / \mathrm{s}$ or after 2002 , the yearly export is $-20,000 \mathrm{~m}^{3} / \mathrm{yr}$. This value is clearly a rough estimate, but considered more reasonable than previous assessment.

Based on the above quantifications, the average longshore transport reaching the delta between 1972 and 2017 ( $\mathrm{LST}_{\mathrm{BA}}$ ) is derived from Eq(2). Accounting for the local contributions $\mathrm{Q}_{\mathrm{sc}}$ and $\mathrm{Q}_{\mathrm{er}}$, and for river export (RE), the $\mathrm{LST}_{\mathrm{BA}}$ best estimate is of the order of $85,000 \mathrm{~m}^{3} / \mathrm{yr}$. This rate is in good agreement with expectations for the region of $\sim 110,000 \mathrm{~m}^{3} / \mathrm{yr}$ at maximum (Santos et al., 2014). Considering the $75 \%$ uncertainty level for $Q_{\text {in }}$, the predicted rate is constrained to an upper limit of $-145,000 \mathrm{~m}^{3} / \mathrm{yr}$.

\section{Comparison with predictions from bulk equations}

The yearly longshore transport rates predicted by the bulk equations share similar trends, characterised by a predominant eastward transport, as expected, with large magnitude fluctuations (Figure 6). An episode of westward transport is noted in 2016-17. The average (1972-2017) LST $_{\text {CERC1 }}$ is $-110,000 \mathrm{~m}^{3} / \mathrm{yr}$ (Table 2), relatively similar to the best estimate from the budget analysis. By contrast, the average $\mathrm{LST}_{\mathrm{CERC} 2}$ rate is approximately two times larger, $-190,000 \mathrm{~m}^{3} / \mathrm{yr}$ (Table 2). It is also noted that the maximum $\mathrm{LST}_{\mathrm{CERC2}}$ rate $\left(-500,000 \mathrm{~m}^{3} / \mathrm{yr}\right)$ generally corresponds to coasts exposed to energetic wave conditions, such as the Monsoon-affected east coast of India (Komar, 1983) or southeast Queensland

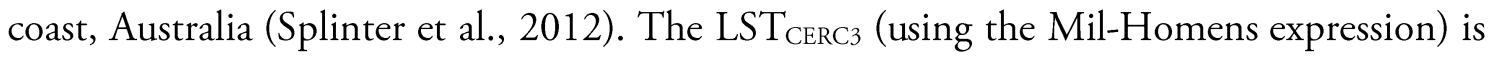
approximately half of LST $_{\text {CERC1, with a mean of }}-40,000 \mathrm{~m}^{3} / \mathrm{yr}$ (Table 2). With the Kamphius expression, the average transport rate ( $\mathrm{LST}_{\mathrm{Kamp}}$ ) is one order of magnitude greater than $\mathrm{LST}_{\mathrm{CERC1}}$, with a mean above $2 \mathrm{Mm}^{3} / \mathrm{yr}$ (Table 2; not shown in Figure 6). 


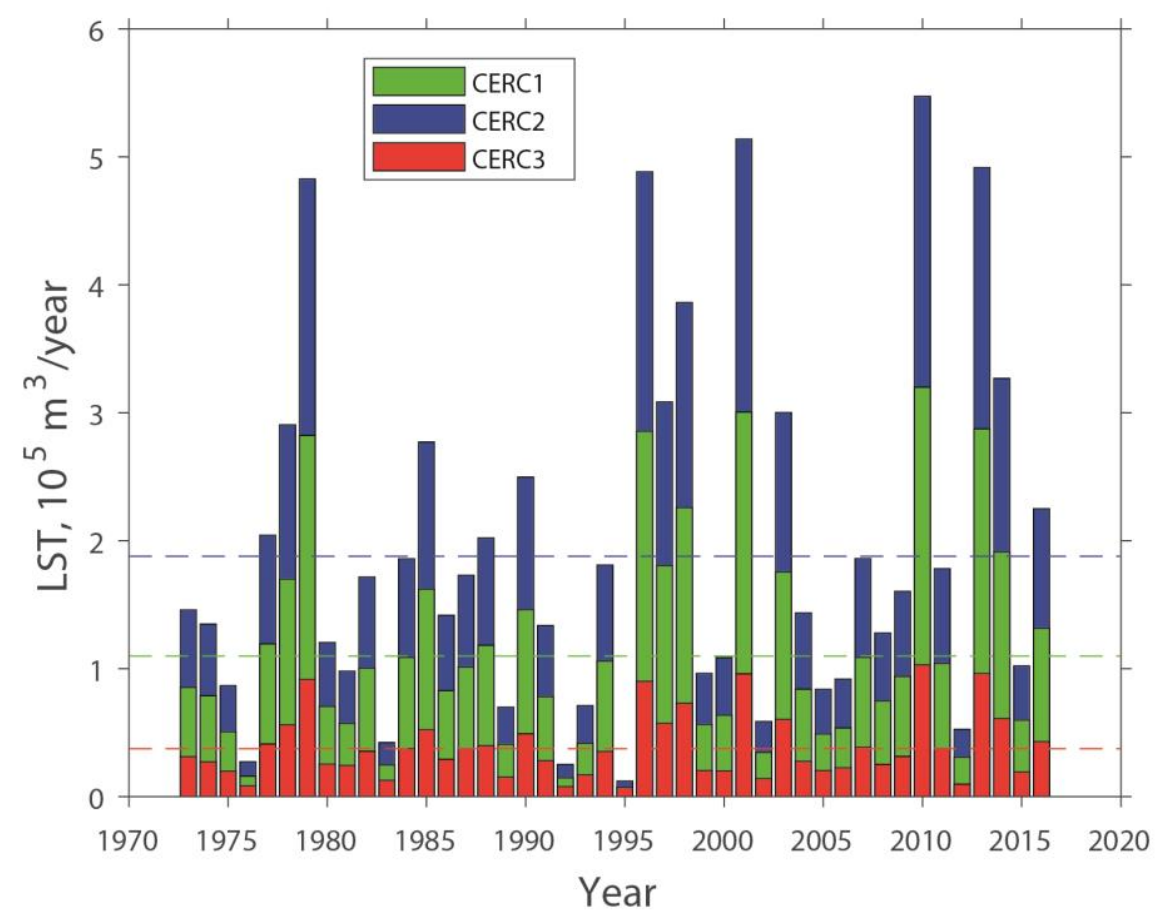

Figure 6. Yearly longshore transport $\left(10^{5} \mathrm{~m}^{3}\right.$, positive eastward) from 1972 to 2017 predicted with the bulk equations $L S T_{\text {CERCI }}$ (green), LST $T_{C E R C 2}$ (blue) and LST $T_{C E R C 3}$ (red) at location $\operatorname{Tr}$ (see Figure 2). The dashed lines represent average values. $L S T_{\text {Kamp }}$ is one order of magnitude larger and not represented.

Table 2. LST rates $\left(\mathrm{m}^{3} / \mathrm{yr}\right)$ obtained from bulk equations 1-4, for the period 1972-2017 and 1972-1980.

\begin{tabular}{|l|l|l|l|l|}
\hline Period & LST $_{\text {CERC1 }}$ & LST $_{\text {CERC2 }}$ & LST $_{\text {CERC3 }}$ & LST $_{\text {Kamp }}$ \\
\hline $1972-2017$ & 109,763 & 187,717 & 37,393 & $2,147,196$ \\
\hline $1995-2017$ & 125,432 & 214,513 & 41,826 & $2,530,466$ \\
\hline
\end{tabular}

The above results exemplify the large variations in between bulk equations predictions, as previously reported in other studies (e.g., Güner et al., 2011, Mil-Homens et al., 2013). Amongst the 4 equations considered, LST $_{\mathrm{CERC1}}$ gives the results that are best in line with expected values in the region and predictions from the budget analysis. It is noted that this equation attempts to represent basic physical processes governing longshore transport without considering the morphodynamic characteristics of the study site. In the formula, these characteristics are embedded in the sediment transport coefficient $\mathrm{K}$, which is a meaningless number devised to achieve agreement between observed and computed LST volumes (Cooper and Pilkey, 2004). Since K accounts for parameters which are both temporally and spatially variable, the concept entailed in the CERC1 formula of a single $\mathrm{K}$ value universally applicable to all beaches is not reasonable. By contrast, in the other equations, morphodynamic effects are accounted for through adjustment of the coefficient 
$\mathrm{K}$ based on the mean grain size in the expression of Valle et al. (1993) and on wave properties in the expression of Mil-Homens et al. (2013) and through input of both the grain size and bed slope in the expression of Kamphuis (1991). Besides, Komar (1988) found that the $\mathrm{K}$ parameter of the original CERC expression was only slightly dependent on the grain size and interpreted this as an indication of the bad quality of the available data used to develop the equation. Many other authors have pointed out that the CERC formula provides only order-of-magnitude accuracy without calibration data (Fowler et al., 1995, Wang et al., 1998). It is therefore probable that the similarity between the $\mathrm{LST}_{\mathrm{BA}}$ and average $\mathrm{LST}_{\mathrm{CERC1}}$ prediction obtained in this study is coincidental.

A source of inaccuracy in LST rate predictions from bulk equations might come from the input wave parameters. The accuracy of these parameters strongly depends of the precision of the topo-bathymetry used for wave propagation. In the present study, only one bathymetry (2016) was implemented in the SWAN model. However, the wave propagation processes were altered by a submerged nearshore bar welding to the beach during the initial development of the modern delta (until $\sim$ 1995; see supplementary material and Garel et al., 2015). Moreover, the simplified bulk formulations fail to account for morphological features on the beach that affect the breaking type of waves and accuracy of LST rate predictions (Kamphuis and Readshaw, 1978, Smith et al., 2009). As an example, if plunging breaking were more frequent than spilling for the more energetic conditions which in turn generate the larger transport rates, one of the main hypotheses of the bulk expressions (spilling breaking) was not fulfilled (Smith et al., 2009). Yet, the results from bulk equations are still highly variable when averaged for the period 1995-2017, characterized by a more typical beach morphological setting (Table 2). It is also noted that although the model was not calibrated, the uncertainties obtained for the bulk expressions are much larger than the possible model corrections, e.g. by fitting the friction coefficient. The large variability of LST predictions highlights the difficulty to select the most adequate bulk equation to be used at a site without additional information to constrain the results.

By contrast, the decadal LST $_{\mathrm{BA}}$ rate is obtained from a "response approach" integrating all potential variables such as morphology, grain size, wave climate, etc. It should therefore be more representative of actual conditions than bulk equations. Application of the method at the Guadiana ebb delta provided a realistic rate of $\sim 85,000 \mathrm{~m}^{3} / \mathrm{yr}$, despite the simple delineation of the sediment transport pathways over the delta (Figure 4). More detailed studies might consider gross longshore transport rates to represent more accurately the sand inputs to the inlet (Bodge, 1993), along with more complex morphological features and sediment pathways for IRM implementation (e.g., Dabees and Kraus, 2008). In any case, sediment budget analyses typically require estimation of quantities that are not very well known (Kraus and Rosati, 1999) and uncertainties should be evaluated (Rosati, 2005). With the proposed approach, the accuracy of sediment transport rates largely depends of 
the amount and quality of the bathymetries used to quantify the volumes of each morphological elements. In particular, water depth accuracy is dependent on many potential errors present in the measurement process (Byrnes et al., 2002). Because of great differences in survey types and resolution, it is generally not possible to assign a single uncertainty to volume changes (Hicks and Hume, 1997). However, it can be assumed that these errors are random and tend to cancel out when considering a large number of surveys. Alternatively, the present reverse application of the IRM allows specifying prediction bounds that define a level of uncertainty for the fitted parameters (in particular $Q_{\text {in }}$ ). The choice of a reasonable confidence interval is arbitrary and depends of the dataset (in particular, small datasets will have very wide intervals). For example, a level of $75 \%$ is considered here because this interval width includes most observations over the study period (Figure 5, thin dashed lines). To reduce at maximum the uncertainty of the results (through the fit of $\mathrm{Eq}(1)$ with observations), the method should therefore include the largest number of bathymetries from the initial development of the delta until it reaches equilibrium in volume. As such, the approach is designed to estimate the transport rate averaged over decades, where shorter time variability is smoothed out. Nevertheless, the results can be used to adjust the $\mathrm{K}$ parameter of the CERC (1984) equation for a specific site in order to address variability over short (e.g., year) time scales, as exemplified in the next section.

\section{LST yearly variability}

Since the coefficient K of the CERC (1984) expression depends on various physical parameters (Rosati et al., 2002), improved LST predictions at a particular site can be obtained if the coefficient is calibrated with data from observations (Bodge and Kraus, 1991, Smith et al., 2009, Wang et al., 2002, Wang et al., 1998). The usage of a constant K value for a site is questionable because this parameter implicitly accounts for factors that vary through time (see Cooper and Pilkey, 2004). However, matching the CERC estimations ( $\mathrm{LST}_{\mathrm{CERC1}}$ ) with the average rate derived from the sediment budget analysis $\left(\mathrm{LST}_{\mathrm{BA}}\right)$ yields a $\mathrm{K}$ coefficient which is representative of the mean conditions at a decadal time scale. This "decadal" $\mathrm{K}$ coefficient might be distinct from the ones representative of the annual conditions that drive the yearly LST. Yet, such tuning of K based on decadal observations provides a mean to quantify more precisely the yearly LST variability in the vicinity of ebb-tidal deltas, especially when compared to the results of generic (nonadjusted) bulk equations. This approach is exemplified based on the results of the present study (although the CERC1 equation and the sediment budget analysis yield similar rates, i.e., the tuned $\mathrm{K}$ should be close to 0.39 ). 
The average LST was computed from 1972 to 2017 at location $\operatorname{Tr}$ using the classical CERC (1984) equation, with $\mathrm{K}$ values ranging from 0.1 to 0.6 . For a $\mathrm{LST}_{\mathrm{BA}}$ rate of 85,000 $\mathrm{m}^{3} / \mathrm{yr}$, the corresponding (tuned) $\mathrm{K}$ is 0.3 . The yearly rate predicted by the adjusted equation ( $\mathrm{LST}_{\mathrm{CAL}}$ ) varies between $-245,000 \mathrm{~m}^{3} / \mathrm{yr}$ and $-5,000 \mathrm{~m}^{3} / \mathrm{yr}$ eastward, and equals $-25,000 \mathrm{~m}^{3}$ westward in 2016-17 (Figure 7). Such high yearly variability may explain the large range of LST rates proposed previously in this coastal area (see Section 2).

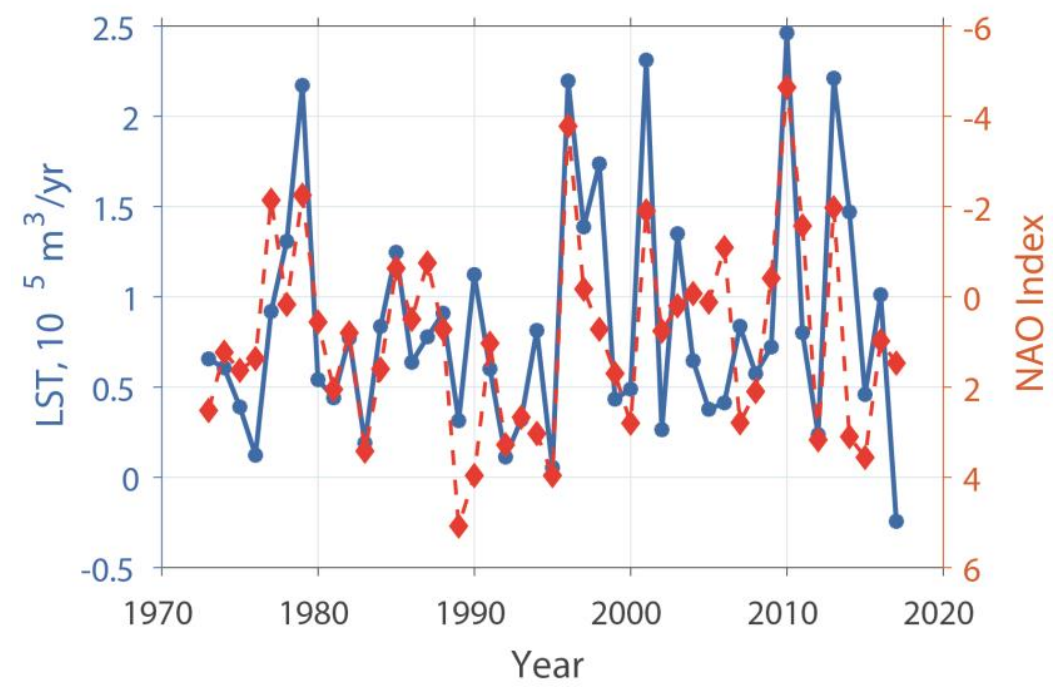

Figure 7. LST CAL (blue line) and NAO variations (dashed red line) from 1972 to 2017. The y-axis of NAO indices is inverted to highlight the relation of (negative) $N A O$ peaks with $L S T_{C A L}$. NAO data were retrieved from Hurrell and NCAR Staff (2017).

It is noted that single years with strong transport $\left(>200,000 \mathrm{~m}^{3} / \mathrm{yr}\right)$ alternate with calmer periods $\left(<100,000 \mathrm{~m}^{3} / \mathrm{yr}\right)$ lasting several years. A similar pattern of peak variability has been reported in previous studies of wave activity in the region, and related to the North Atlantic Oscillation (NAO; see Almeida et al., 2011, Plomaritis et al., 2015). The NAO has long been known to affect climate variability in the Northern Hemisphere (Hurrell, 1995) and, consequently, the wave climate arriving at the west coast of Europe (e.g., Bacon and Carter, 1993, Dodet et al., 2010, Martínez-Asensio et al., 2016), in particular in winter (e.g., Bromirski and Cayan, 2015). Likewise, previous studies have reported relations between large scale climate indices and yearly LST estimates, for example in East Australia (Splinter et al., 2012). At the study site, Figure 7 features a good correspondence between

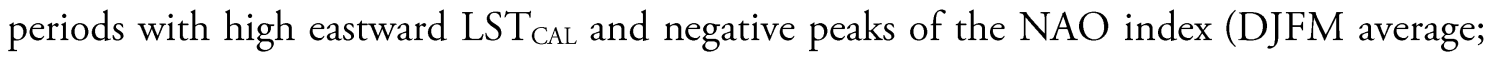
Hurrell and NCAR Staff, 2017) below an approximate threshold value of -1 . For example, the 5 largest transport rates $(>200,000 \mathrm{~m} 3 / \mathrm{yr}$ ) of the time series are associated to the lowest NAO index values, between -1.9 and -4.6 (only the low index of 1977 is not associated to a large LST rate). Notably, the largest LST $_{\text {CAL }}$ rate (in 2010) corresponds to the lowest NAO index value. Such NAO index threshold have been previously reported in relation to large wave activity in the Gulf of Cadiz (Plomaritis et al., 2015), confirming that the magnitude 
of longshore transport is mainly controlled by storminess. Along the western coast of Europe, modulation at multi-decadal time-scales of the longshore sediment transport by the atmospheric circulation in the north Atlantic has been evidenced at wave built barriers (Costas et al., 2016, Poirier et al., 2017). The present analysis verifies that climate variability may also affect significantly the longshore transport rates at a yearly scale. Future studies should evaluate how this temporal variability affects the coastal evolution in the region.

\section{Conclusions}

The present study proposes a method to estimate average (decadal) LST rates in the vicinity of modern ebb-tidal deltas. A sediment budget analysis is conducted to specify the sediment transport pathways towards the outer shoal and the associated rates (other than LST). These contributions are balanced with the total sediment input rate to the shoal, estimated based on an inverse application of the IRM, yielding a best estimate of the average LST rate during the study period along with upper bounds (at confidence levels) that are often desirable for the design of management and planning strategies.

The method has been applied to the 45 years (1972-2017) development of the modern ebb-tidal delta that followed jetty installation at the mouth of the Guadiana Estuary. The results indicate an average LST rate of $\sim 85,000 \mathrm{~m}^{3} / \mathrm{yr}$ (best estimate), in good agreement with expectations for the region. Considering a $75 \%$ uncertainty level for $\mathrm{Q}_{\text {in }}$, the rate is $-145,000 \mathrm{~m}^{3} / \mathrm{yr}$, at maximum. For comparison, the average LST predictions from bulk equations for the same period vary by more than one order of magnitude, illustrating their well-known large variability. Nevertheless, the average (decadal) rate from the sediment budget analysis can be used to adjust the K coefficient of the CERC (1984) equation to local conditions for the quantification of LST rate variations at shorter time scales. As an example, it is shown that yearly absolute rates at the study site vary by a factor of -50 $\left(5,000-245,000 \mathrm{~m}^{3} / \mathrm{yr}\right)$ in relation to $\mathrm{NAO}$ index variations.

The method is applicable to ebb-tidal deltas where the main transport pathways towards the outer shoal can be specified. It is also required that the outer shoal development from an early to a relatively mature state is well-documented by bathymetric maps. Hence the approach applies to ebb-tidal deltas that developed - or were largely disrupted - relatively recently. Many of such systems can be found worldwide. Examples include ebb deltas subject to extensive dredging of the outer shoal, affected by jetty or breakwater installation or created by (artificial or natural) barrier breaching (e.g., Beck and Wang, 2019, Buonaiuto et al., 2008, Castelle et al., 2007, Cox and Howe, 2012, Dabees and Kraus, 2008, Hansen and Knowles, 1988, Kaminski et al., 2010, Kana and McKee, 2003, Patsch and Griggs, 2008, Vila-Concejo et al., 2004).Overall, the approach provides an alternative mean to constrain the average LST rate over decades that smooth out any shorter-term 
variability. Where the modern delta development is particularly well-documented (e.g., at a yearly frequency), the approach could be implemented to estimate the average LST at shorter time scales. Finally, with the ongoing development of satellite derived bathymetry, the method could be applied to an increasing number of sites where echo-sounding surveys are not conducted frequently.

\section{Acknowledgements}

Wave hindcast data were provided by Puertos del Estado (Spanish Ministry of Public Works). The following institutions in Portugal are acknowledged for providing some of the bathymetric maps used in this study: Ministry of Public Works (MPW); Hydrographic Institute (IH); and, Port and Maritime Transport Institute (IPTM). The work of Erwan Garel was supported by FCT research contract IF/00661/2014/CP1234. Alejandro LópezRuiz acknowledges support from the Spanish Ministry of Science, Innovation and Universities (Programa Estatal de Investigación, Desarrollo e Innovación orientada a los RETOS de la sociedad, Ref. CTM2017-89531-R).

\section{References}

Aagaard T, Nielsen J, Jensen SG, Friderichsen J. 2004. Longshore sediment transport and coastal erosion at Skallingen, Denmark. Geografisk Tidsskrift-Danish Journal of Geography 104: 5-14. DOI: $10.1080 / 00167223.2004 .10649499$

Almeida LP, Ferreira Ó, Vousdoukas MI, Dodet G. 2011. Historical variation and trends in storminess along the Portuguese South Coast. Nat. Hazards Earth Syst. Sci. 11: 2407-2417. DOI: 10.5194/nhess-11-2407-2011

Andrade C. 1990. O ambiante de barreira da ria formosa Andrade. In Departamento de Geologia. Universidade de Lisboa: Lisbon; 645.

Bacon S, Carter DJT. 1993. A connection between mean wave height and atmospheric pressure gradient in the North Atlantic. International Journal of Climatology 13: 423-436. DOI: doi: $10.1002 /$ joc.3370130406

Bayram A, Larson M, Hanson H. 2007. A new formula for the total longshore sediment transport rate. Coastal Engineering 54: 700-710. DOI: https://doi.org/10.1016/j.coastaleng.2007.04.001

Bayram A, Larson M, Miller HC, Kraus NC. 2001. Cross-shore distribution of longshore sediment transport: comparison between predictive formulas and field measurements. Coastal Engineering 44: 79-99. DOI: https://doi.org/10.1016/S0378-3839(01)00023-0

Beck TM, Wang P. 2019. Morphodynamics of barrier-inlet systems in the context of regional sediment management, with case studies from west-central Florida, USA. Ocean \& Coastal Management 177: 31-51. DOI: https://doi.org/10.1016/j.ocecoaman.2019.04.022 
Bergillos RJ, López-Ruiz A, Ortega-Sánchez M, Masselink G, Losada MA. 2016. Implications of delta retreat on wave propagation and longshore sediment transport-Guadalfeo case study (southern Spain). Marine Geology 382: 1-16. DOI: https://doi.org/10.1016/j.margeo.2016.09.011

Bettencourt P. 1994. Les environnements sédimentaires de la côte Sotavento (Algarve, Sud Portugal) et leur évolution Holocène et actuelle. Univeristé de Bordeaux I: Bordeaux; 586.

Bijker EW. 1971. Longshore Transport Computations. Journal of Waterways, Harbors and Coastal Engineering Division 97: 687-703

Bodge KR. 1993. Gross Transport Effects and Sand Management Strategy at Inlets. Journal of Coastal Research: 111-124

Bodge KR, Dean RG. 1987. Short-term impoundment of longshore transport. In Coastal Sediments'87, ASCE (ed): New York; 468-483.

Bodge KR, Kraus NC. 1991. Critical examination of longshore transport rate magnitude. In Proceedings of Coastal Sediments '91. ASCE: Seattle, Washington; 139-155.

Booij N, Ris RC, Holthuijsen LH. 1999. A third-generation wave model for coastal regions: 1. Model description and validation. Journal of Geophysical Research: Oceans 104: 7649-7666. DOI: doi:10.1029/98JC02622

Bowen AJ, Inman DL. 1966. Budget of littoral sands in the vicinity of Point Arguello, California. In U.S. Army Coastal Engineering Research Center Technical Memo No. 19.

Bromirski PD, Cayan DR. 2015. Wave power variability and trends across the North Atlantic influenced by decadal climate patterns. Journal of Geophysical Research: Oceans 120: 3419-3443. DOI: doi:10.1002/2014JC010440

Bruno RO, Dean RG, Gable CG. 1981. Longshore Transport Evaluations at a Detached Breakwater. In 17th International Conference on Coastal Engineering, ASCE (ed): New York; 14531475.

Bruun P, Gerritsen F. 1959. Natural bypassing of sand at coastal inlets. Journal of the Waterways and Harbors Division, ASCE 85: 401-412

Buonaiuto FS, Bokuniewicz HJ, FitzGerald DM. 2008. Principal Component Analysis of Morphology Change at a Tidal Inlet: Shinnecock Inlet, New York. Journal of Coastal Research 24: 867-875

Byrnes MR, Baker JL, Li F. 2002. Quantifying potential measurement errors and uncertainties associated with bathymetric change analysis. In ERDC/CHL CHETN-IV-50. US Army Corps of Engineers, Engineer Research and Development Center, Coastal and Hydraulics Laboratory: Vicksburg, MS. 
Carr EE, Kraus NC. 2001. Morphologic Asymmetries at Entrances to Tidal Inlets. US Army Corps of Engineers.

Castelle B, Bourget J, Molnar N, Strauss D, Deschamps S, Tomlinson R. 2007. Dynamics of a wave-dominated tidal inlet and influence on adjacent beaches, Currumbin Creek, Gold Coast, Australia. Coastal Engineering 54: 77-90. DOI: http://dx.doi.org/10.1016/j.coastaleng.2006.08.007

CEEPYC. 1979. Plan de estudio de la dinámica littoral de la Provincia de Huelva. Dirección General de Puertos y Costas: Mardid; 37.

CERC. 1984. Shore Protection Manual. USACE (ed). Coastal Engineering Research Center: Vicksburg.

Ciavola P, Taborda R, Ferreira Ó, Dias JA. 1997. Field Measurements of Longshore Sand Transport and Control Processes on a Steep Meso-Tidal Beach in Portugal. Journal of Coastal Research 13: 1119-1129

Cooper JAG, Pilkey OH. 2004. Longshore Drift: Trapped in an Expected Universe. Journal of Sedimentary Research 74: 599-606. DOI: 10.1306/022204740599

Costa M, Silva R, Vitorino J. 2001. Contribução para o estudo do clima de agitação marítima na costa portuguesa. In Proceedings of 2as Jornadas Portuguesas de Engenharia Costeira e Portuária. International Navigation Association PIANC: Sines, Portugal.

Costas S, Naughton F, Goble R, Renssen H. 2016. Windiness spells in SW Europe since the last glacial maximum. Earth and Planetary Science Letters 436: 82-92. DOI: https://doi.org/10.1016/j.epsl.2015.12.023

Costas S, Ramires M, de Sousa LB, Mendes I, Ferreira O. 2018. Surficial sediment texture database for SW Iberia Atlantic Margin. Earth Syst. Sci. Data Discuss. DOI: https://doi.org/10.5194/essd2018-30,

Cowell PJ, Stive MJF, Niedoroda AW, Swift DJP, Vriend HJd, Buijsman MC, J. NR, Roy PS, Kaminsky GM, Cleveringa J, Reed CW, Boer PLd. 2003a. The Coastal-Tract (Part 2): Applications of Aggregated Modeling of Lower-Order Coastal Change. Journal of Coastal Research 19: 828-848

Cowell PJ, Stive MJF, Niedoroda AW, Vriend HJd, Swift DJP, Kaminsky GM, Capobianco M. 2003b. The Coastal-Tract (Part 1 ): A Conceptual Approach to Aggregated Modeling of LowOrder Coastal Change. Journal of Coastal Research 19: 812-827

Cox R, Howe D. 2012. Tweed River entrance and bypass sediment dynamics. In Coastal Engineering.

Cuena GJ. 1991. Proyecto de regeneración de la playa de Isla Cristina. Servicio de Costas, MOPT; 100. 
Dabees MA, Kraus NC. 2004. Evaluation of Ebb-Tidal Shoals as a Sand Source for Beach Nourishment: General Methodology with Reservoir Model Analysis. In 17th National Conf. on Beach Preservation Technology, FSBPA (ed): Tallahassee, FL; 21.

Dabees MA, Kraus NC. 2005. General Methodology for Inlet Reservoir Model Analysis of Sand Management Near Tidal Inlets. In Coastal Dynamics 2005.

Dabees MA, Kraus NC. 2008. Cumulative effets of channel and ebb shoal dredging on inlet evolution in southwest Florida, USA. In 31st International Conference on Coastal Engineering 2008: WS; 2303-2315.

Dean RG, Berek EP, Gable CG, Seymour RJ. 1982. Longshore transport determined by an efficient trap. In Coastal Engineering; 954-968.

Dean RG, Dalrymple RA. 2004. Coastal Processes with Engineering Applications. Cambridge University Press: Cambridge, UK

Dean RG, Walton TL. 1975. Sediment transport processes in the vicinity of inlets with special reference to sand trapping. In Geology and Engineering, Cronin LE (ed). Academic Press; 129-149.

Dodet G, Bertin X, Taborda R. 2010. Wave climate variability in the North-East Atlantic Ocean over the last six decades. Ocean Modelling 31: 120-131. DOI: https://doi.org/10.1016/j.ocemod.2009.10.010

Esteves LS, Williams JJ, Lisniowski MA. 2009. Measuring and modelling longshore sediment transport. Estuarine, Coastal and Shelf Science 83: 47-59. DOI: https://doi.org/10.1016/j.ecss.2009.03.020

FitzGerald DM, Kraus NC, Hands EB. 2000. Natural mechanisms of sediment bypassing at tidal inlets. US Army Corps of Engineers; 9.

Fowler JE, Rosati JD, Hamilton DG, Smith JM. 1995. Development of a Large-Scale Laboratory Facility for Longshore Sediment Transport Research, The CERCular. U.S. Army Engineer Waterways Experiment Station: Vicksburg, Missisippi.

Garel E. 2017. Efficient dredging strategy for channel maintenance of the Guadiana ebb-delta. In Coastal Dynamics 2017: Helsingor, Denmark; 12.

Garel E, D'Alimonte D. 2017. Continuous river discharge monitoring with bottom-mounted current profilers at narrow tidal estuaries. Continental Shelf Research 133: 1-12. DOI: http://dx.doi.org/10.1016/j.csr.2016.12.001

Garel E, Ferreira Ó. 2011. Effects of the Alqueva Dam on Sediment Fluxes at the Mouth of the Guadiana Estuary. Journal of Coastal Research SI 64: 1505-1509 
Garel E, Sousa C, Ferreira Ó. 2015. Sand bypass and updrift beach evolution after jetty construction at an ebb-tidal delta. Estuarine, Coastal and Shelf Science 167, Part A: 4-13. DOI: http://dx.doi.org/10.1016/j.ecss.2015.05.044

Garel E, Sousa C, Ferreira Ó, Morales JA. 2014. Decadal morphological response of an ebb-tidal delta and down-drift beach to artificial breaching and inlet stabilisation. Geomorphology 216: 1325. DOI: http://dx.doi.org/10.1016/j.geomorph.2014.03.031

Gaudiano DJ, Kana TW. 2001. Shoal bypassing in mixed energy inlets: Geomorphic variables and empirical predictions for nine South Carolina inlets. Journal of Coastal Research 17: 280-291

Gonzalez R, Dias JMA, Ferreira Ó. 2001. Recent rapid evolution of the Guadiana Estuary mouth (southwestern Iberian Peninsula) Journal of Coastal Research Proceedings of International Coastal Symposium 2000: 516-527

Granja H, Froidefrond JM, Pera T. 1984. Processus d'evolution morpho-sedimentaire de la Ria Formosa (Portugal). Bulletin de l'Institut de Géologie du Bassin d'Aquitaine, Bordeaux 36: 37-50

Güner HAA, Yüksel Y, Çevik EÖ. 2011. Longshore Sediment Transport—Field Data and Estimations Using Neural Networks, Numerical Model, and Empirical Models. Journal of Coastal Research: 311-324. DOI: 10.2112/JCOASTRES-D-11-00074.1

Hansen M, Knowles S. 1988. Ebb-Tidal Delta Response to Jetty Construction at Three South Carolina Inlets. In Hydrodynamics and Sediment Dynamics of Tidal Inlets, Aubrey D, Weishar L (eds). Springer New York; 364-381.

Hanson H, Aarninkhof S, Capobianco M, Jim, xe, nez JA, Larson M, Nicholls RJ, Plant NG, Southgate HN, Steetzel HJ, Stive MJF, Vriend HJd. 2003. Modelling of Coastal Evolution on Yearly to Decadal Time Scales. Journal of Coastal Research 19: 790-811

Hayes MO. 1980. General morphology and sediment patterns in tidal inlets. Sedimentary Geology 26: 139-156. DOI: http://dx.doi.org/10.1016/0037-0738(80)90009-3

Hicks DM, Hume TM. 1997. Determining Sand Volumes and Bathymetric Change on an EbbTidal Delta. Journal of Coastal Research 13: 407-416

Hurrell J, NCAR Staff. 2017. The Climate Data Guide: Hurrell North Atlantic Oscillation (NAO) Index (station-based). National Center for Atmospheric Research; Retrieved on 07 Nov 2017 from https://climatedataguide.ucar.edu/climate-data/hurrell-north-atlantic-oscillation-nao-index-stationbased.

Hurrell JW. 1995. Decadal Trends in the North Atlantic Oscillation: Regional Temperatures and Precipitation. Science 269: 676-679. DOI: 10.1126/science.269.5224.676

Inman DL, Zampol JA, White TE, Hanes DM, Waldorf BW, Kastens KA. 1980. Field Measurements of Sand Motion in the Surf Zone. In Coastal Engineering 1980; 1215-1234. 
Kaminski GM, Ruggiero P, Buijsman MC, McCandless D, Gelfenbaum G. 2010. Historical evolution of the Columbia River littoral cell. Marine Geology 273: 96-126

Kaminsky GM, Ruggiero P, Buijsman MC, McCandless D, Gelfenbaum G. 2010. Historical evolution of the Columbia River littoral cell. Marine Geology 273: 96-126. DOI: https://doi.org/10.1016/j.margeo.2010.02.006

Kamphuis JW. 1991. Alongshore Sediment Transport Rate. Journal of Waterway, Port, Coastal, and Ocean Engineering 117: 624-640. DOI: doi:10.1061/(ASCE)0733-950X(1991)117:6(624)

Kamphuis JW, Readshaw JS. 1978. A Model Study of Alongshore Sediment Transport Rate. In 16th International Conference on Coastal Engineering. ASCE: Hamburg, Germany; 1656-1674.

Kana TW, McKee PA. 2003. Relocation of Captain Sams inlet-20 years later. In Coastal Sediments '03. World Scientist; 12.

Kelley JT, Barber DC, Belknap DF, Fitzgerald DM, van Heteren S, Dickson SM. 2005. Sand Budgets at geological, historical and contemporary time scales for a developed beach system, Saco Bay, Maine, USA. Marine Geology 214: 117-142

Komar PD. 1983. Chapter 2 Nearshore Currents and Sand Transport on Beaches. In Elsevier Oceanography Series, Johns B (ed). Elsevier; 67-109.

Komar PD. 1988. Enviromental controls on littoral sand transport. In $21^{\text {st }}$ Conference on Coastal Engineering: Torremolinos, Spain.

Komar PD. 1998. Beach Processes and Sedimentation

Komar PD, Inman DL. 1970. Longshore sand transport on beaches. Journal of Geophysical Research 75: 5914-5927. DOI: doi:10.1029/JC075i030p05914

Kraus NC. 2000. Reservoir model of ebb-tidal delta evolution and sand bypassing. Journal of Waterway, Port, Coastal, and Ocean Engineering 126: 305-313

Kraus NC. 2002. Reservoir Model for Calculating Natural Sand Bypassing and Change in Volume of Ebb-tidal Shoals, Part 1: Description. In ERFC/CHL CHETN-IV-39, ERDC USA (ed): Vicksburg, MS.

Kraus NC. 2009. Engineering of tidal inlets and morphologic consequences. In Handbook of Coastal and Ocean Engineering, Kim YC (ed). World Scientific: Singapore; 867-901.

Kraus NC, Dean JL. 1987. Longshore sediment transport rate distributions measured by trap. In Coastal Sediments'87; 881-896.

Kraus NC, Rosati JD. 1999. Estimation of Uncertainty in Coastal-Sediment Budgets at Inlets. In Coastal Engineering Technical Note CETN IV-16. U.S. Army Engineer Research and Development Center, Coastal and Hydraulics Laboratory: Vicksburg, MS; 12. 
Larson M, Kraus N. 1995. Prediction of cross-shore sediment transport at different spatial and temporal scales. Marine Geology 126: 111-127. DOI: https://doi.org/10.1016/00253227(95)00068-A

Lee GH, Birkemeier WA. 1993. Beach and nearshore survey data: 1985-1991. In CERC Field Research facility, US Army Corps of Engineers.

Longuet-Higgins MS. 1970. Longshore currents generated by obliquely incident sea waves: 1. Journal of Geophysical Research 75: 6778-6789. DOI: doi:10.1029/JC075i033p06778

López-Ruiz A, Bergillos RJ, Lira-Loarca A, Ortega-Sánchez M. 2018a. A methodology for the longterm simulation and uncertainty analysis of the operational lifetime performance of wave energy converter arrays. Energy 153: 126-135. DOI: https://doi.org/10.1016/j.energy.2018.04.018

López-Ruiz A, Bergillos RJ, Raffo-Caballero JM, Ortega-Sánchez M. 2018b. Towards an optimum design of wave energy converter arrays through an integrated approach of life cycle performance and operational capacity. Applied Energy 209: 20-32. DOI: https://doi.org/10.1016/j.apenergy.2017.10.062

López-Ruiz A, Ortega-Sánchez M, Baquerizo A, Losada MÁ. 2014. A note on alongshore sediment transport on weakly curvilinear coasts and its implications. Coastal Engineering 88: 143-153. DOI: https://doi.org/10.1016/j.coastaleng.2014.03.001

Martínez-Asensio A, Tsimplis MN, Marcos M, Feng X, Gomis D, Jordà G, Josey SA. 2016. Response of the North Atlantic wave climate to atmospheric modes of variability. International Journal of Climatology 36: 1210-1225. DOI: doi:10.1002/joc.4415

Mil-Homens J, Ranasinghe R, van Thiel de Vries JSM, Stive MJF. 2013. Re-evaluation and improvement of three commonly used bulk longshore sediment transport formulas. Coastal Engineering 75: 29-39. DOI: https://doi.org/10.1016/j.coastaleng.2013.01.004

Morales JA. 1997. Evolution and facies architecture of the mesotidal Guadiana River delta (S.W. Spain-Portugal). Marine Geology 138: 127-148

Patsch K, Griggs G. 2008. A sand budget for the Santa Barbara Littoral Cell, California. Marine Geology 252: 50-61. DOI: https://doi.org/10.1016/j.margeo.2008.01.013

Plomaritis TA, Benavente J, Laiz I, Del Río L. 2015. Variability in storm climate along the Gulf of Cadiz: the role of large scale atmospheric forcing and implications to coastal hazards. Climate Dynamics 45: 2499-2514. DOI: 10.1007/s00382-015-2486-4

Poirier C, Tessier B, Chaumillon E. 2017. Climate control on late Holocene high-energy sedimentation along coasts of the northeastern Atlantic Ocean. Palaeogeography, $\begin{array}{llll}\text { Palaeoclimatology, } & \text { Palaeoecology } & \text { 785: } & \text { DOI: }\end{array}$ https://doi.org/10.1016/j.palaeo.2017.07.037 
Portela L. 2006. Sediment delivery from the Guadiana estuary to the coastal ocean. Journal of Coastal Research: 1819-1823

Rosati JD. 2005. Concepts in Sediment Budgets. Journal of Coastal Research: 307-322. DOI: $10.2112 / 02-475 \mathrm{a} .1$

Rosati JD, Walton TL, Bodge K. 2002. Longshore sediment transport. U.S. Army Corps of Engineers: Washington, DC

Santos FD, Lopes AM, Moniz G, Ramos L, Taborda R. 2014. Gestáo da Zona Costeira - O Desafio da Mudança. Litoral RFdGdTd (ed); 260.

Schoonees JS, Theron AK. 1993. Review of the field-data base for longshore sediment transport. Coastal Engineering 19: 1-25. DOI: https://doi.org/10.1016/0378-3839(93)90017-3

Schoonees JS, Theron AK. 2001. Improvement of the most accurate longshore transport formula. Coastal Engineering Proceedings. DOI: 10.9753/icce.v25.\%p

Schoonees JS, Theron AK, Bevis D. 2006. Shoreline accretion and sand transport at groynes inside the Port of Richards Bay. Coastal Engineering 53: 1045-1058. DOI: https://doi.org/10.1016/j.coastaleng.2006.06.006

Smith ER, Wang P, Ebersole BA, Zhang J. 2009. Dependence of Total Longshore Sediment Transport Rates on Incident Wave Parameters and Breaker Type. Journal of Coastal Research: 675683. DOI: $10.2112 / 07-0919.1$

Splinter KD, Davidson MA, Golshani A, Tomlinson R. 2012. Climate controls on longshore sediment transport. Continental Shelf Research 48: 146-156. DOI: https://doi.org/10.1016/j.csr.2012.07.018

Stauble DK. 1998. Techniques for measuring and analyzing inlet ebb-shoal evolution. In Coastal Engineering Technical Note IV-13. US Army Engineering Research and Development Center, Coastal and Hydraulics Research Laboratory: Vicksburg, MS.

Stive MJF, Aarninkhof SGJ, Hamm L, Hanson H, Larson M, Wijnberg KM, Nicholls RJ, Capobianco M. 2002. Variability of shore and shoreline evolution. Coastal Engineering 47: 211235. DOI: https://doi.org/10.1016/S0378-3839(02)00126-6

Tonk A, Masselink G. 2005. Evaluation of Longshore Transport Equations with OBS Sensors, Streamer Traps, and Fluorescent Tracer. Journal of Coastal Research: 915-931. DOI: 10.2112/040209.1

Valle Rd, Medina R, Losada MA. 1993. Dependence of Coefficient K on Grain Size. Journal of Waterway, Port, Coastal, and Ocean Engineering 119: 568-574. DOI: doi:10.1061/(ASCE)0733950X(1993)119:5(568) 
Van Wellen E, Chadwick AJ, Mason T. 2000. A review and assessment of longshore sediment transport equations for coarse-grained beaches. Coastal Engineering 40: 243-275. DOI: https://doi.org/10.1016/S0378-3839(00)00031-4

Vicente C, Pereira MC. 2001. Estudo das condiçóes ambientais no estuário do Guadiana e zona costeira adjacente. 2a Fase: Componente de dinâmica costeira. (LNEC) LNdEC (ed): Lisbon.

Vila-Concejo A, Ferreira Ó, Morris BD, Matias A, Dias JMA. 2004. Lessons from inlet relocation: examples from Southern Portugal. Coastal Engineering 51: 967-990. DOI: http://dx.doi.org/10.1016/j.coastaleng.2004.07.019

Wang P, Ernest RS, Bruce AE. 2002. Large-Scale Laboratory Measurements of Longshore Sediment Transport under Spilling and Plunging Breakers. Journal of Coastal Research 18: 118135

Wang P, Kraus NC. 1999. Longshore Sediment Transport Rate Measured by Short-Term Impoundment. Journal of Waterway, Port, Coastal, and Ocean Engineering 125: 118-126. DOI: doi:10.1061/(ASCE)0733-950X(1999)125:3(118)

Wang P, Kraus NC, Davis RA. 1998. Total Longshore Sediment Transport Rate in the Surf Zone: Field Measurements and Empirical Predictions. Journal of Coastal Research 14: 269-282 


\section{SUPPLEMENTARY MATERIAL}

Bathymetric maps of the Guadiana ebb-tidal delta from 1969 to 2017 with location of the outer shoal, updrift lateral bar and inlet channel areas (red, green and blue boundaries, respectively). The contour interval is $0.10 \mathrm{~m}$.

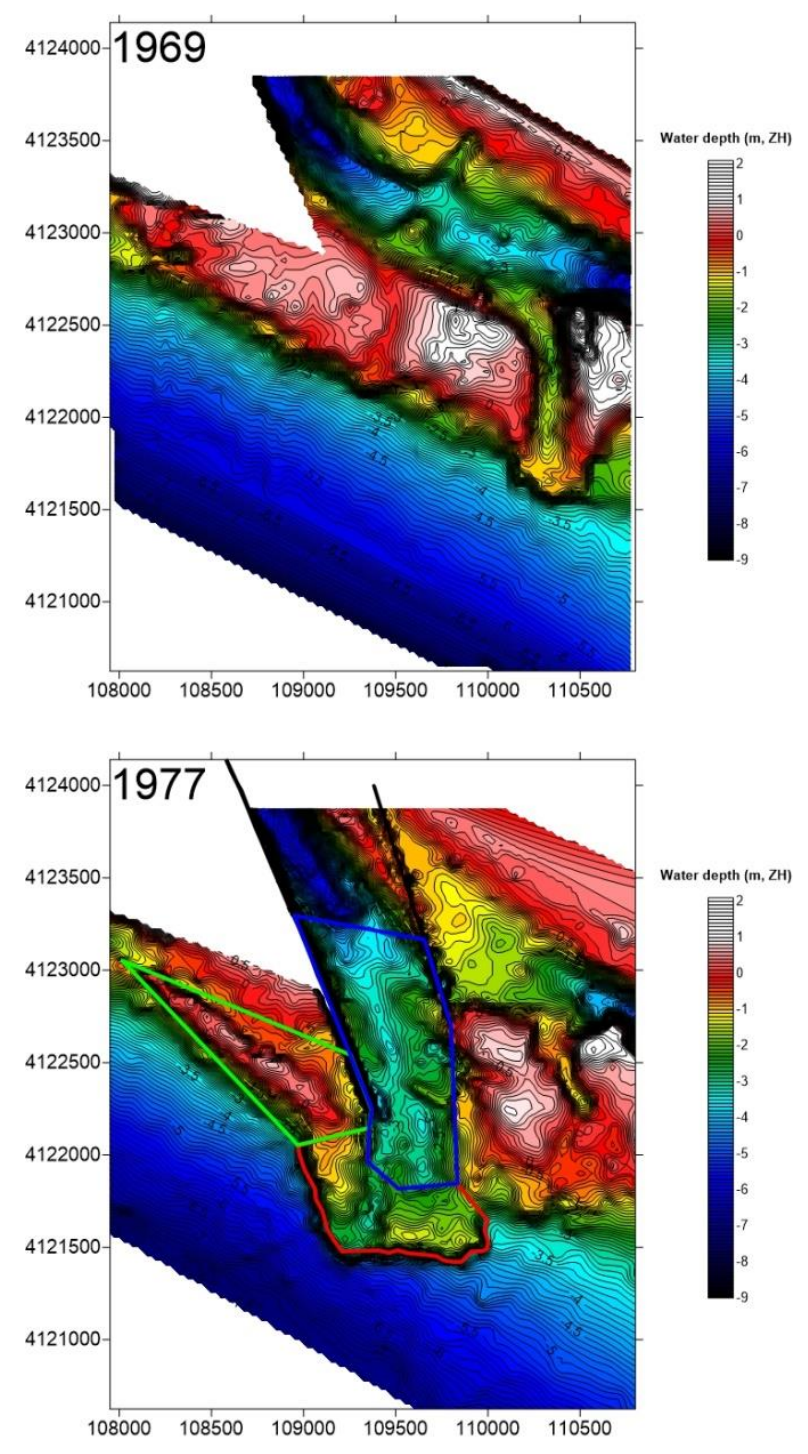



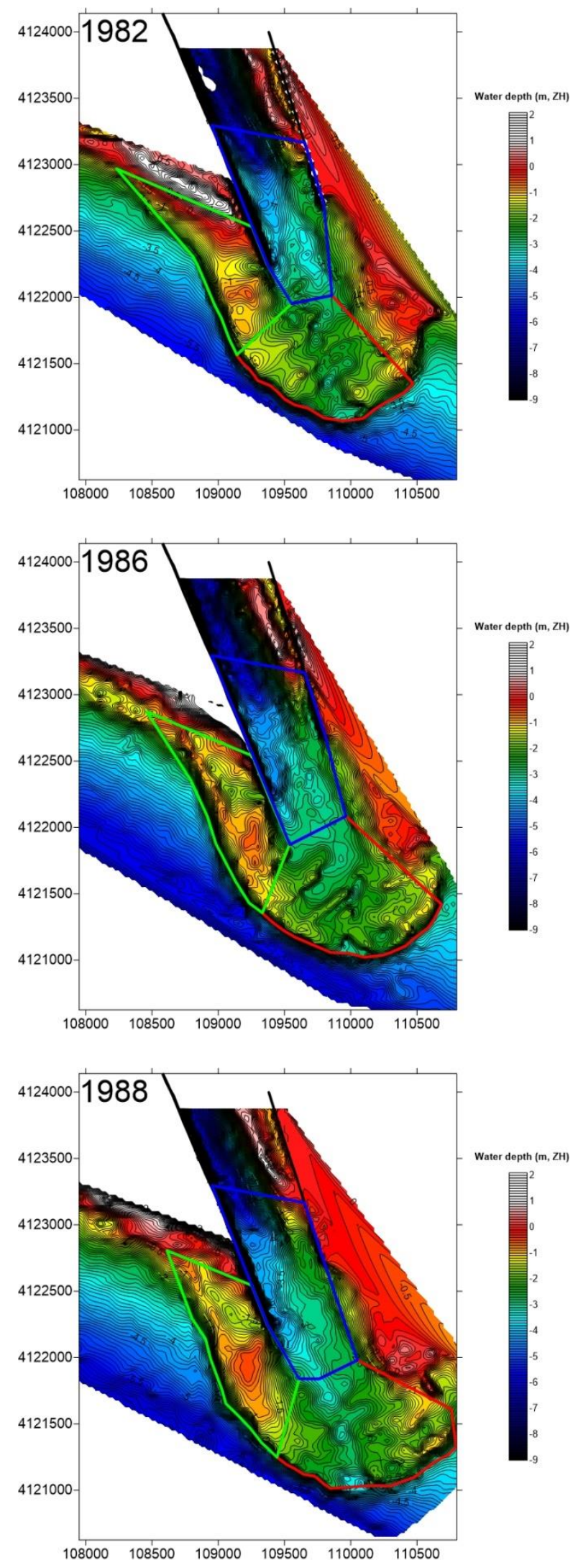

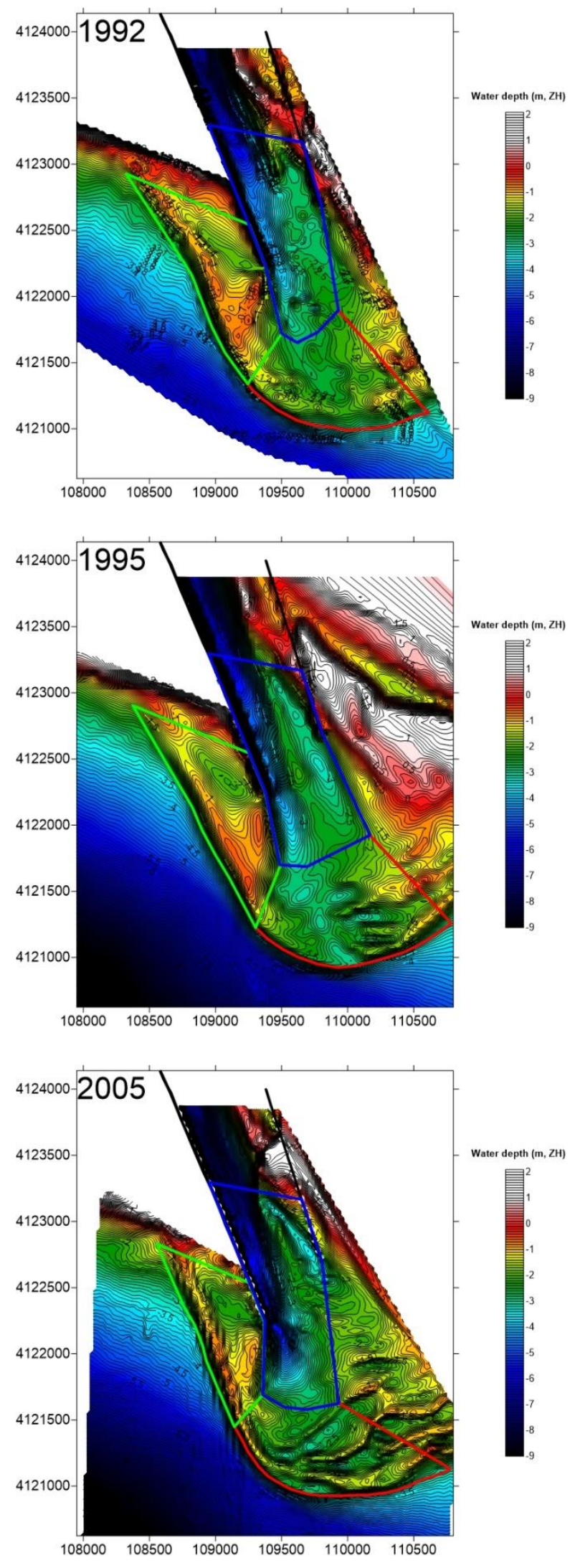

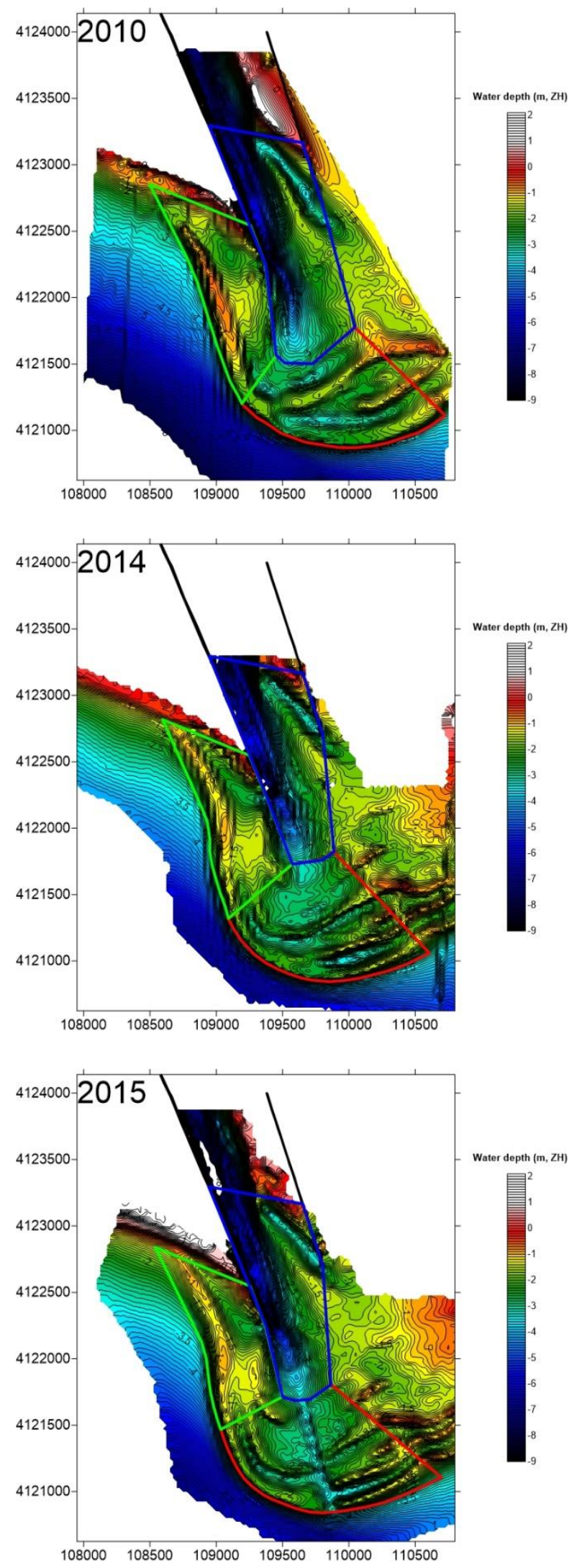

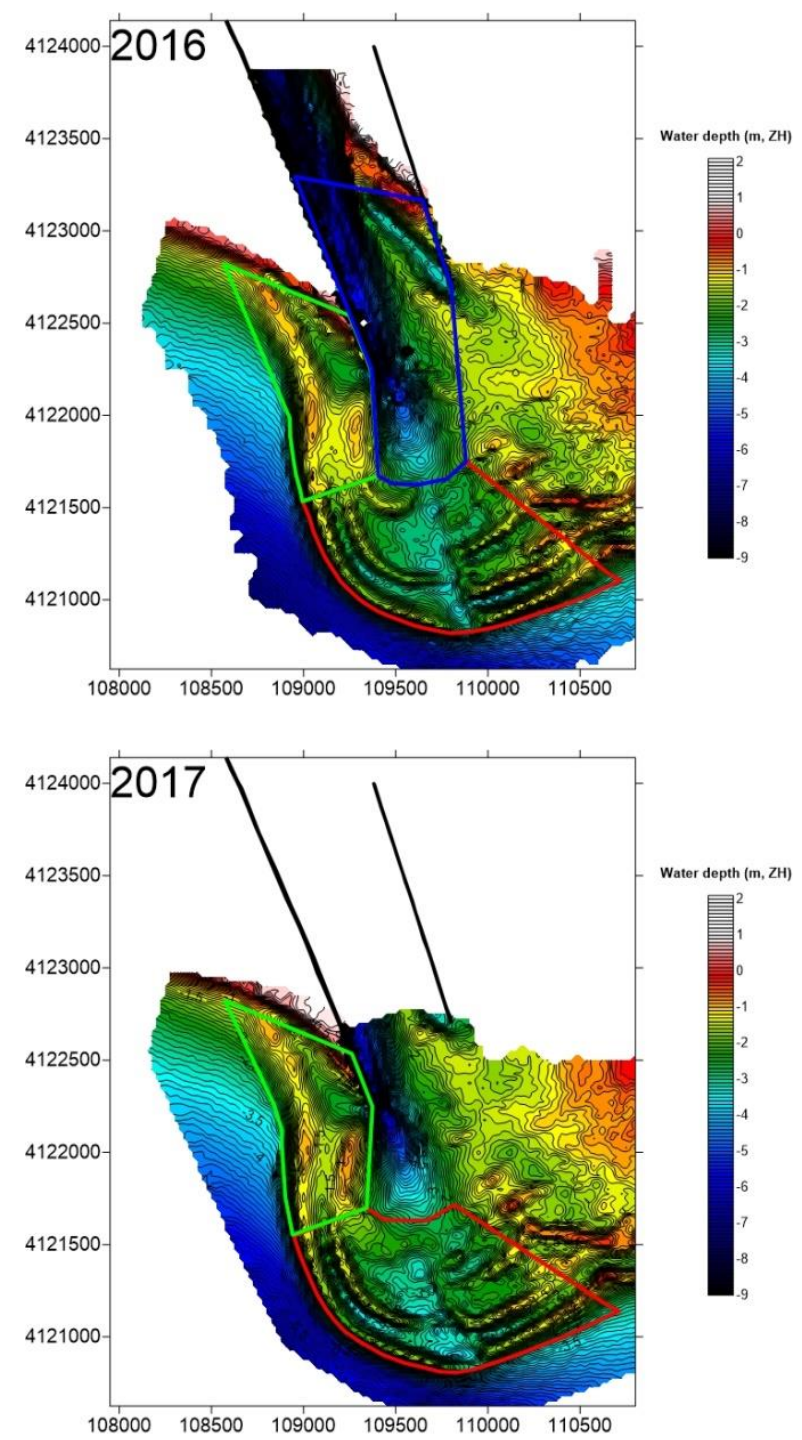